\title{
TWO FUNDAMENTALLY DIFFERENT TYPES OF SUBMARINE CANYONS ALONG THE CONTINENTAL MARGIN OF EQUATORIAL GUINEA
}

\section{Zane R. Jobe ${ }^{\text {a }}$, Donald R. Lowe ${ }^{\mathrm{a}}$, and Steven J. Uchytil ${ }^{\mathrm{b}}$}

A. Department of Geological and Environmental Sciences, Stanford University, 450 Serra Mall, Building 320, Stanford, CA, 94305, USA

B. Hess Corporation, One Allen Center, 500 Dallas Street, Houston, TX, 77002

Email: Zane R. Jobe Zanejobe@gmail.com

Donald R. Lowe drlowe@stanford.edu

Steven J. Uchytil suchytil@hess.com

Corresponding author: Zane Jobe

$\begin{array}{ll}\text { Address: } & 450 \text { Serra Mall, Bldg } 320 \\ & \text { Stanford, CA, } 94305 \text { USA }\end{array}$

Phone: (817) $422-3600$

Fax: $\quad$ (650) $725-0979$

\begin{abstract}
Most submarine canyons are erosive conduits cut deeply into the world's continental shelves through which sediment is transported from areas of high coastal sediment supply onto large submarine fans. However, many submarine canyons in areas of low sediment supply do not have associated submarine fans and show significantly different morphologies and depositional processes from those of 'classic' canyons. Using three-dimensional seismic reflection and core data, this study contrasts these two types of submarine canyons and proposes a bipartite classification scheme.

The continental margin of Equatorial Guinea, West Africa during the late Cretaceous was dominated by a classic, erosional, sand-rich, submarine canyon system. This system was abandoned during the Paleogene, but the relict topography was reactivated in the Miocene during tectonic uplift. A subsequent decrease in sediment supply resulted in a drastic transformation in canyon morphology and activity, initiating the 'Benito' canyon system. This non-typical canyon system is aggradational rather than erosional, does not indent the shelf edge and has no downslope sediment apron. Smooth, draping seismic reflections indicate that hemipelagic deposition is the chief depositional process aggrading the canyons. Intra-canyon lateral accretion
\end{abstract}


deposits indicate that canyon concavity is maintained by thick (>150 m), dilute, turbidity currents. There is little evidence for erosion, mass wasting, or sand-rich deposition in the Benito canyon system. When a canyon loses flow access, usually due to piracy, it is abandoned and eventually filled. During canyon abandonment, fluid escape causes the successive formation of 'cross-canyon ridges' and pockmark trains along buried canyon axes.

Based on comparison of canyons in the study area, we recognize two main types of submarine canyons: 'Type I' canyons indent the shelf edge and are linked to areas of high coarse-grained sediment supply, generating erosive canyon morphologies, sandrich fill, and large downslope submarine fans/aprons. 'Type II' canyons do not indent the shelf edge and exhibit smooth, aggradational morphologies, mud-rich fill, and a lack of downslope fans/aprons. Type I canyons are dominated by erosive, sandy turbidity currents and mass wasting, whereas hemipelagic deposition and dilute, sluggish turbidity currents are the main depositional processes sculpting Type II canyons. This morphology-based classification scheme can be used to help predict depositional processes, grain size distributions, and petroleum prospectivity of any submarine canyon.

Keywords (8): continental slope deposition; submarine canyon evolution; hemipelagic sedimentation; turbidity current deposition; seismic geomorphology; lateral accretion; pockmark; fluid escape 


\section{Introduction}

Submarine canyons, first spotlighted by Shepard (1936), are the primary conduits for the transport of clastic detritus from the continents into the deep sea (Normark and Carlson, 2003) and their sandy fill can form major petroleum reservoirs (Stow and Mayall, 2000). Nearly every continental margin is dissected by submarine canyons that display a range of morphologies and depositional process (Shepard, 1981). Many canyons are long-lived features that may persist for tens of millions of years (Shepard 1981; Weaver et al., 2000; Zhu, 2007; Zhu et al., 2009), and all play key roles in the evolution of continental margins. As a result, submarine canyon origins, morphology, depositional processes, and evolution have been at the focus of many recent sedimentological and seismic geomorphological studies (Peakall et al., 2000; Weaver et al., 2000; Bulat and Long, 2001; Deptuck et al., 2003; Posamentier and Kolla, 2003; Deptuck et al., 2007; Arzola et al., 2008; Lastras, et al., 2009).

Classically-described submarine canyons, here named "Type I" canyons, have predominantly erosional morphologies and in many ways are morphologically comparable to subaerial canyons. Most are eroded deeply into the shelf edge (e.g., Normark, 1970a), some heading in estuaries or the surf zone. Tributaries, multiple thalwegs, a V-shaped cross section, terraces, and scalloped, slumped edges are other characteristic features of Type I canyons (Fig. 1; Shepard and Emery, 1973; Shepard, 1981; Gervais et al., 2004; Bertoni and Cartwright, 2005; Cunningham et al., 2005; 
Antobreh and Krastel, 2006; Lastras et al., 2009; Mountjoy et al., 2009; Armitage, et al., 2010). Many are associated with areas of high sediment supply (Weaver et al., 2000), such as coastal mountain belts (Gervais et al., 2004), large fluvial systems (Burke, 1972; Shepard and Emery, 1973; Shepard, 1981; McGregor et al., 1982; McHargue and Webb, 1986; O'Connell et al., 1987; Green and Uken, 2008; Yu et al., 2009) or vigorous longshore drift cells (Moore, 1969; Burke, 1972; Inman et al., 1976; Paull et al., 2005; Covault et al., 2007). These high sediment supply areas commonly have sharply defined shelf edges, steep upper slopes, and numerous shelf-indenting canyons (Fig. 1). With ready access to coarse-grained shelfal sediments, Type I canyons are thought to be dominated by erosive turbidity currents and mass transport processes (Ericson et al., 1952; Shepard, 1981; Normark and Gutmacher, 1988; Normark and Piper, 1991; Weaver et al., 2000; Paull et al., 2003). These canyons at times erode through highly indurated bedrock and the canyon fill is generally coarse grained, including sand and conglomerate (Paull et al., 2005; Anderson et al., 2006). Type I canyons commonly pass downslope into large, coarse-grained submarine fans (Fig. 1; Normark, 1970a; Burke, 1972; Shepard and Emery, 1973; McHargue and Webb, 1986; Fildani and Normark, 2004; Lastras et al., 2009).

Other submarine canyons have very different morphologies, erosional processes, and depositional processes from those of Type I canyons (Fig. 1). These canyons, "Type II" canyons, do not indent the shelf edge, rather heading on the slope in 300-700 m 
water depth (Fig. 1; Twichell and Roberts, 1982). Their morphologies commonly include a U shaped cross section, smooth walls lacking terraces or slumps, aggradational evolution, and mud-rich canyon fill (Fig. 1; Blum and Okamura, 1992; Field et al., 1999; Zhu et al., 2009; Straub and Mohrig, 2009). In most cases, there is little or no sediment apron or submarine fan downslope of Type II canyons (Fig. 1) due to their location in areas of low sediment supply (Stow and Piper, 1984; Field et al., 1999). Smooth, muted shelf edges and shallower slope angles are characteristically developed near these canyons (Fig. 1). Hemipelagic deposition, dilute turbidity currents, and bottom currents have been invoked to explain the formation of Type II canyons (Marani et al., 1993; Field et al., 1999; Zhu et al., 2009; Straub and Mohrig, 2009).

Using a high resolution 3-D seismic survey from offshore Equatorial Guinea, this study documents the evolution and transformation of a submarine canyon system from a sand-rich, erosive, Type I canyon system to a slope-confined, mud-rich, aggradational, Type II canyon system (Fig. 1). The theme of this special issue, the "stratigraphic evolution of deep-water architecture," is documented here in terms of depositional process, grain size, canyon fill architecture, and the large-scale reorganization of the depositional system and continental margin. Finally, we compare the morphology, fill, and downdip expression of modern and ancient canyons in the study area (Fig. 1) and develop a bipartite classification scheme for submarine canyons. 


\section{Rio Muni Basin of Equatorial Guinea, West Africa}

\subsection{Tectonic setting and basin evolution}

The Rio Muni Basin (Fig. 2) of Equatorial Guinea was initiated in the Early

Cretaceous during the opening of the South Atlantic Ocean (Turner et al., 2003). Its conjugate basin is the petroliferous Sergipe Alagoas Basin in Brazil (Meyers et al., 1996; Lawrence et al., 2002). Occupying a transtensional (i.e., sheared) position on the west African margin, the Rio Muni Basin is dissected by the Ascension fracture zone (Fig. 2A; Meyers et al., 1996; Turner et al., 2003). Transitional ocean crust underlies the basin, resulting in complex tectonostratigraphy (Meyers et al., 1996; Turner, 1999; Dailly et al., 2002; Wilson et al., 2003). Rifting was initiated in the Aptian at 117 Ma (Fig. 3; Meyers et al., 1996; Lawrence et al., 2002; Turner et al., 2003) and was accompanied by sapropelic lacustrine source rock and evaporite deposition (Emery et al., 1975; Lehner and De Ruiter, 1977; Turner 1999). By the mid-Albian (Fig. 3; Turner, 1995; 1999), the 'transitional' rifting phase began, during which shallow marine carbonate and clastic units were deposited (Emery et al., 1975; Lehner and De Ruiter, 1977). Rifting was complete by end Turonian ( $89 \mathrm{Ma}$ ) and is marked by a composite drift unconformity (Turner 1995, 1999). The Rio Muni Basin has subsequently evolved as a siliciclasticdominated passive margin with a well-developed submarine canyon and fan-channel system (Fig. 3; Lehner and De Ruiter, 1977) that contains a number of major petroleum reservoirs (Ross and Hempstead, 1993; Dailly et al., 2002; Frynas, 2004). 


\subsection{Physiography and Sediment Supply}

The Rio Muni Basin lies almost entirely offshore, with only meager Aptian outcrops near the coast (Fig. 2B; Emery et al., 1975; Meyers et al., 1996). The modern Equatorial Guinea margin has an average shelf width of $18 \mathrm{~km}$ (Fig. 2B) and the slope break lies at about $100 \mathrm{~m}$ water depth. The $2.5^{\circ}$ continental slope is fairly steep (cf. Pratson and Haxby, 1996) and intersects the continental rise at about $2000 \mathrm{~m}$ water depth (Fig. 2B).

The modern coastal wind regime is dominated by winds out of the southwest (Burke 1972; Emery et al., 1974), creating a northward longshore drift (Fig. 2; Servain et al., 1985; Mariano et al., 1995). Mud-rich plumes from the nearby Mitemele River as well as the Ogooue River in Gabon (Fig. 2B) are transported northward into the Rio Muni Basin by the northbound coastal currents (Jourdin et al., 2006). The Niger River (Fig. 2A) is another possible fine-grained sediment source, as its plume increases turbidity in large areas of the Gulf of Guinea (Burke, 1972; Emery et al., 1974) and the southbound Equatorial undercurrent may transport Niger-sourced mud into the study area (Jourdin et al., 2006). The small Benito River likely supplies fine and coarse sediment locally to the study area (Fig. 2B). The study area probably receives sediment from many of these sources in variable quantities depending on local seasons and other factors: heavy seasonal rainfall and storm events favor local river discharge, as well as 
re-suspended shelfal sediments (e.g., Fan et al., 2004), whereas fair-weather longshore currents favor the large river plumes.

\section{Dataset and Methods}

The subsurface dataset in the study area of the Rio Muni Basin consists of a three-dimensional (3-D) seismic reflection survey, borehole, and core data provided by Hess Corporation. The 3-D seismic data (Fig. 4) begins $5 \mathrm{~km}$ from the shoreline and covers $\sim 400 \mathrm{~km}^{2}(15 \times 26 \mathrm{~km})$ of the shelf and upper to mid slope, to $1100 \mathrm{~m}$ water depth. The data is 3-D pre-stack time-migrated and $90^{\circ}$ phase-rotated so that a change in impedance represents a zero crossing. Inline and crossline spacing is $12.5 \mathrm{~m}$ and sample rate is $2 \mathrm{~ms}$. Dominant frequency in the shallow subsurface interval is $\sim 70$ Hertz, generating a resolution of $\sim 7 \mathrm{~m}(\lambda / 4)$ and detection of $\sim 1 \mathrm{~m}(\lambda / 25)$. All seismic sections in this paper show peaks in black and troughs in white. Depth measurements were calculated using seismic velocities of $1500 \mathrm{~m} / \mathrm{s}$ for seawater and $2000 \mathrm{~m} / \mathrm{s}$ for the shallow subsurface sediment. Uncased boreholes yield little lithologic data but provide biostratigraphic age determination. Shallow boreholes for drilling-hazard assessment, however, provide valuable lithologic calibration for the modern seafloor and shallow subsurface to depths of $120 \mathrm{~m}$ (Fig. 5). These boreholes indicate that, although the shelf contains considerable amounts of sand, the slope is dominated by clay (Fig. 5). The little sand present on the slope appears to be concentrated in the canyon thalwegs and pockmarks, where amplitude values are highest (Fig. 5). 


\section{The Benito canyon system: characteristics and depositional processes}

\subsection{General characterization of the seafloor}

The canyons that occupy the modern seafloor in the study area are informally named the 'Benito' canyon system after the adjacent Benito River (Fig. 2B). There are two active canyons on the modern seafloor in the study area, the B-North and B-South canyons as well as the abandoned B-Central canyon (Fig. 4). The canyon heads do not indent the shelf, instead located about $3 \mathrm{~km}$ beyond the shelf edge in $\sim 280 \mathrm{~m}$ water depth (Figs. 4, 5). Canyon heads show no evidence of large-scale mass wasting (Fig. 4). The Benito canyons are aggradational and have smooth surface morphologies and Ushaped cross sections (Fig. 4). They average $1300 \mathrm{~m}$ wide and $200 \mathrm{~ms}$, or $150 \mathrm{~m}$ deep, and have fairly steep banks, with slopes ranging from $14^{\circ}$ of $19^{\circ}$. Canyon thalweg gradients average $3^{\circ}$, only slightly greater than the regional upper slope gradient. Canyons are straight or display low (1.14 average) sinuosity (Fig. 1). Canyons are commonly linked by straight, slope-parallel canyons/gullies that also display U-shaped and smooth morphologies.

Seismic data across the study area show remarkably uniform and continuous reflections, both in the canyon fill and inter-canyon areas, that stack to form an aggradational to slightly progradational continental margin (Fig. 6). Canyon evolution ranges from purely aggradational to slightly offstacking (Fig. 6), but canyons never migrate more than they aggrade (Cf. Fig. 21C of Kolla et al., 2001). Individual canyons 
display more than $800 \mathrm{~m}$ of aggradation and maximum lateral migration of less than $1000 \mathrm{~m}$ since the early Miocene. This aggradational character stands in direct contrast to Type I canyons, which are predominantly incisional (Twichell and Roberts, 1982; Pratson et al., 1994).

The seafloor in the inter-canyon areas is essentially flat except for the presence of local sediment waves and pockmarks. The sediment waves (Figs. 4, 5) occur near the outer bends of sinuous canyons and migrate upslope (Fig. 7D). They show average wavelengths of $575 \mathrm{~m}$ and amplitudes of $15 \mathrm{~ms}$, or $11 \mathrm{~m}$, and are asymmetric, with steep sides facing downslope (Fig. 7D). Pockmarks are more or less circular depressions on the seafloor that average $400 \mathrm{~m}$ in diameter and $50 \mathrm{~ms}$ ( $38 \mathrm{~m}$ ) deep and tend to be aligned in trains over the axes of abandoned, infilled canyons (Fig. 4; section 5.4.3).

\subsection{Depositional elements}

Three main seismic depositional elements have been identified in the Benito canyon system: conformable reflection elements (CREs; Fig. 6), canyon lateral accretion packages (CLAPs; Fig. 7), and thalweg high amplitude reflection elements (HARs; Fig. 8). Sediments across the study area in both the canyons and the inter-canyon areas consist of CREs. CLAPs and HARs are sporadic and are restricted to the canyon fill.

\subsubsection{Conformable Reflection Elements (CREs)}

The predominant depositional element in the Benito canyon system, the conformable reflection element (CRE) consists of draping reflections that are uniform 
for long distances laterally and downslope, up to 14 and $16 \mathrm{~km}$, respectively (Fig. 6). They can be traced with remarkable continuity in inter-canyon areas and across the canyons and pockmarks with little or no thickness change (Fig. 6). CREs are occasionally truncated by HARs (Fig. 6), but never truncate other reflections. CRE amplitudes are generally uniform from inter- to intra-canyon areas, and core data demonstrates that they are composed largely of clay (Figs. 5, 6A). The remarkable continuity and consistent amplitude response over long distances, both inside and outside of canyons, and the clay lithology suggests that CREs form as drapes that mantle pre-existing topography and are not related to current activity.

\subsubsection{Canyon Lateral Accretion Packages (CLAPs)}

Canyon Lateral Accretion Packages (CLAPs) are sediment packages that occur in sinuous and straight Benito canyons, both on the modern seafloor (Fig. 7A) and in the subsurface (Fig 7B). They are made up of stacked, inclined reflections that build out from one canyon wall into the thalweg and are sigmoidal in shape, forming sediment wedges that extend from the top edge to the thalweg of a canyon (Fig. 7). Although commonly conformable in character, some CLAPs show internal erosion surfaces (Fig. 7A). Much larger than many other lateral accretion deposits (Abreu et al., 2003), CLAPs average $750 \mathrm{~m}$ wide and $130 \mathrm{~m}$ (175 ms) thick. Well developed CLAPs occur in the low sinuosity (1.07) B-south canyon (Figs. 7A, 7B), where accretion is directed from inner to outer bend. The aggradational canyon evolution has a slight migrational component, 
which correlates with the direction of CLAP accretion (Figs. 7A, B). The B-North canyons also shows inner- to outer-bend accretion (Fig. 7D). CLAPs also occur in straight canyons, commonly those that are oriented oblique to slope (Fig. 7C). CLAPs in these canyons accrete downslope, yielding aggradational canyons that slowly migrate downslope (Figs. 7C, D).

\subsubsection{Thalweg High Amplitude Reflection Elements (HARs)}

Thalweg high amplitude reflection (HAR) elements (Fig. 8) are rare in the canyon fill, consisting of high amplitude reflections ('HARs', sensu Flood et al., 1991) that occupy the canyon thalweg. HARs are ordinarily $10 \mathrm{~ms}(8 \mathrm{~m})$ thick, $500 \mathrm{~m}$ long, and 200 $\mathrm{m}$ wide and are restricted to the canyon axes (Fig. 8). Laterally discontinuous and concave in shape, HARs stack at random in the canyons and at times truncate CREs.

\subsection{Depositional processes}

Based on the geometries and relationships of depositional elements, we interpret multiple depositional processes that act to sculpt the Benito canyon system. CREs created by hemipelagic deposition aggrades the canyon system while canyon concavity is maintained by turbidity currents of two types: thick, dilute, weakly erosional currents that mainly deposit CLAPs and vigorous, erosive currents that mostly deposit HARs.

\subsubsection{Hemipelagic deposition}

The CREs in the Benito canyon system drape the canyons without erosion of underlying reflections, amplitude changes, or thickness variations (Fig. 6). General 
hydraulic considerations indicate that currents moving over the seafloor will be influenced by seafloor topography and will not deposit uniform and continuous sediment layers both inside and outside of canyons. Also, sediments correlated to CREs in cores C4 and C5 (Fig. 5) are mainly clay that lack primary current structures. We conclude that CREs are the result of hemipelagic deposition, defined by Stow et al (2001) as "a complex process involving both vertical settling and slow lateral advection through the water column." Hemipelagic deposits form continuous clay drapes that mantle and aggrade local submarine topography (Thornton, 1984), and they have been shown to promote aggradation of submarine canyons and gullies (Stow and Piper, 1984; Field et al., 1999). Because CREs are the most abundant sediments in the study area, hemipelagic deposition is inferred to be the dominant depositional process in the Benito canyon system and responsible for its aggradational evolution.

\subsubsection{Thick, dilute, muddy turbidity currents}

Lateral accretion deposits are known to be deposited by both turbidity currents and contour/bottom currents. Contour/bottom currents tend to form canyons, 'furrows,' or 'moats' oriented parallel to the regional slope with accretion occurring in a consistent direction in response to Coriolis forcing (van Weering et al., 1998; Damuth and Olson, 2001; Shipboard Scientific Party, 2002) or due to impingement with slopetransverse canyons (Zhu 2007; Zhu et al., 2009). However, the study area is nearly at the equator $\left(1.6^{\circ} \mathrm{N}\right)$, where Coriolis forces are weak. Furthermore, accretion occurs on 
both sides of the canyons and in different directions within the same canyon (Fig. 7), a feature not reported from contour-current-dominated systems but commonly reported in turbidity-current-dominated systems (Abreu et al., 2003; Arnott, 2007; Dykstra and Kneller, 2009). Although slight erosion does take place, the smooth, aggradational CLAP morphology suggests that the flows must be weak and predominantly depositional. Available core data, the low amplitude values, and the lack of erosive features suggest that most CLAPs are composed of mud (silt + clay) and deposited by dilute turbidity currents that were weakly or non erosive.

The modern B-North and B-South canyons show inner- to outer-bend accretion related to shear stress variations as turbidity currents moving down the canyons pass through meander bends (Figs. 7A, B, D). The momentum of the current causes higher shear stress on the outer bend, resulting in minor bank erosion or non-deposition, and lower shear stresses on the inner bend, resulting in CLAP deposition and growth (Fig. 7). Many CLAPs are also documented in straight canyons (Fig. 7C), where no shear stress asymmetry is expected. This suggests that the currents were not confined by the canyons but also flowed down the inter-canyon areas. Upon reaching an oblique or slope-parallel canyon, these flows deposited mud on the upslope canyon bank and eroded the downslope canyon bank. The thickness, grain size, and morphology of CLAPs contrast with the lateral accretion deposits studied by Abreu et al (2003), where erosive, sand-rich flows cause abundant erosion of the outer bank and drove the 
migration of a highly sinuous $(>2.5)$, leveed channel and the emplacement of thin $(<40$ m) lateral accretion deposits thinner than the channel depth. The mud-rich, weakly erosional CLAPs (Fig. 7) are as thick (> $150 \mathrm{~m}$ ) as the canyons are deep and are likely formed by turbidity currents of a much different character than those envisioned by Abreu et al. (2003).

Many studies have described these thick, dilute, muddy, sluggish turbidity flows that lack the ability to erode. Moore (1969) discusses shelfal turbid-layers and their evolution into dilute turbidity currents. Shepard et al. (1977) document dilute, sluggish currents that flow down submarine canyons. Stow and Bowen (1980) estimate thicknesses of 100s of meters, widths of $25 \mathrm{~km}$, and velocities of $10-20 \mathrm{~cm} / \mathrm{s}$ for such dilute flows. Wynn et al. (2000) describe dilute turbidity currents that form sediment waves and estimate flow thicknesses up to $450 \mathrm{~m}$. Straub and Mohrig (2009) suggest that thick, dilute, unconfined turbidity currents form an aggradational, mud-rich canyon system on the Brunei margin. This study suggests that thick, dilute, sluggish turbidity currents were responsible for the maintenance of canyon concavity and CLAP deposition. The thickness of the CLAPs and the presence of sediment waves on outer canyon bends (Fig. 7D) caused by flow stripping (sensu Piper and Normark, 1983), and CLAP formation in oblique and slope-parallel canyons indicates that these flows commonly exceed $150 \mathrm{~m}$ thick and are not fully confined by the canyons, occupying many canyons at once as well as the inter-canyon areas. 


\subsubsection{Erosional, sand-rich turbidity currents}

HARs display the highest amplitudes in the study area (Fig. 8), interpreted to result from the presence of coarse-grained sediment. Also, HARs truncate other deposition elements, suggesting that the depositing flows were erosive. This erosive character suggests that HARs were deposited by energetic flows carrying coarsegrained sediment. Sandy, high- or low-density turbidity currents (sensu Lowe, 1982) could provide the necessary shear stress to erode mud-rich, cohesive CREs and transport sand downslope within the canyons. Flow stripping of these currents around canyon bends may also result in the local deposition of sand in the overbank and on sediment waves, as evidenced by amplitude contrasts on sediment wave crests and around outer canyon bends (Fig. 5). The occurrence of HARs in multiple canyons at the same stratigraphic level, notably between Horizons 5 and 6 (Figs. 6B, 8), suggests that these currents may have been related to the regional influx of coarse sediment driven by allocyclic forcing.

\section{Canyon evolution}

Based on the mapping of the 3D seismic reflection dataset, the evolution of submarine canyons in the study area can be divided into four phases:

1) A Late Cretaceous stage during which sand-rich, erosional, Type I submarine canyons occupied the slope, shown in Horizon 1 (Fig. 9A); 
2) A Paleogene quiescent period, when hemipelagic deposition partially infilled canyon topography, shown in Horizon 2 (Fig. 9B);

3) Early Miocene re-initiation of the relict canyon topography due to regional tectonic uplift and increased sediment supply, shown in Horizon 3 (Fig. 9C); and

4) The Neogene development and evolution of the aggradational, mud-rich, Type II Benito canyon system, shown in Horizons 4-9 (Figs. 9D-I); this evolution includes the abandonment of canyons and their evolution into pockmark trains.

\subsection{Late Cretaceous submarine canyon development}

Three wide $(>4 \mathrm{~km})$ submarine canyons occupied the study area during the Late Cretaceous (Figs. 6B, 8, 9A; Lehner and De Ruiter, 1977; Dailly et al., 2002; Jobe and Hewlett, 2007). These canyons will be referred to as the northern, central, and southern Cretaceous canyons (Figs. 8, 9A). The central Cretaceous canyon contains reservoirs that make up the 'Okume complex' oil field, which currently produces more than 70,000 barrels per day (www.hess.com). Seismic and borehole data demonstrate that the central canyon was sand-rich and erosive (Dutta, 2009). Core taken in the canyon fill consists of thick-bedded sandstone turbidites and mud-clast conglomerates, with some interbedded debris flow deposits and thin-bedded turbidites (Dutta, 2009). The southern and northern Cretaceous canyons lie near the boundaries of the survey (Figs. $6 \mathrm{~B}, 8,9 \mathrm{~A}$ ) and have not been cored. However, they are presumed to contain coarse- 
grained fill due to their high amplitudes and morphological similarities to the central Cretaceous canyon.

The Cretaceous canyon system includes large slump features and scalloped, faulted margins (Figs. 6B, 8, 9A) consistent with those of a Type I canyon system. Furthermore, the canyon fill is sand-rich, suggesting that the canyons indented the shelf and were sculpted chiefly by erosive, energetic turbidity currents and mass-wasting. This high sediment supply may have been enhanced by the young, hot rift shoulder topography of the West African margin during this time (cf. Meyers et al., 1996).

\subsubsection{Canyon-margin faulting}

The Cretaceous canyon system was flanked by large bounding faults that parallel the canyon axes (Figs. 6B, 8). These syn-sedimentary normal faults display growth and are listric at depth (Figs. 6B, 8), where bedding can be steeply rotated (Fig. 6B). The faults are unusual in that they extend into the subsurface beneath the canyons (Fig. 6B) rather than soling out in the canyon thalweg, as most bank failures do. Where opposing faults meet, a local zone of compression (Fig. 8) creates toe-thrusts and intra-canyon topography (Fig. 9A). The faults remained active through most of the Tertiary, but are not active on the modern seafloor.

The faulting is interpreted to reflect "rotated channel-margin sliding" sensu Sawyer et al. (2007) and are similar to some outcrop examples of erosion-dominated channels (Williams et al., 1965; Cronin et al., 2007). These faults are the result of 
undercutting by large, erosive turbidity currents, which removed support of and caused instability of the adjacent canyon walls (Figs. 6B, 8; Fig. 14 of Sawyer et al., 2007). Also, the subsequent aggradation of the inter-canyon areas likely facilitated sliding by providing additional overburden. The topography created by these slides influenced subsequent flows in the canyons, impacting the distribution of sand (Fig. 9A; Cf. Armitage et al., 2009). The canyon-margin sliding continued throughout the Paleogene and early Neogene until an equilibrium was re-established in the late Neogene (Figs. $6 \mathrm{~B}, 8)$. The absence of faults modifying the modern seafloor and other mass wasting features in the Benito canyon system suggest that canyon-margin faulting is not active, and the currents in the modern Benito canyon system do not undercut or destabilize the canyon banks.

\subsection{Paleogene quiescence}

Beginning at $65 \mathrm{Ma}$ (Figs. 3, 6), the character of the depositional system in the study area changed significantly. Decreased sediment supply during the Paleogene (Turner, 1995) caused the widespread deposition of CREs, partially infilling the Cretaceous canyon system (Figs. 6B, 9B). Although inactive and infilling, the relict Cretaceous canyon topography and fault scarps persisted on the seafloor throughout the Paleogene (Fig. 9B). During the time interval between Horizons 1 and 3, (65 Ma 23 Ma; Figs. 6, 9B), CREs were the only depositional elements deposited in the study area. Borehole data demonstrate that the CREs between Horizons 1 and 3 are 
composed primarily of clay (Fig. 5), suggesting that the study area was completely starved of coarse-grained sediment during the Paleogene. This interpretation is reinforced by Turner (1995), who indicates that this time period was one of tectonic and sedimentological quiescence and reports the widespread deposition of draping units in the Rio Muni Basin.

\subsection{Benito canyon system: initiation}

Horizon 3 is a rugose surface above the conformable Paleogene section and represents an erosional unconformity (Figs. 6, 9C) in the study area. This unconformity is attributed to crustal uplift associated with the formation of the Cameroon volcanic line (CVL) at 23 Ma (Fig. 3; Seranne et al., 1992; Meyers et al., 1998; Turner, 1999; Marzoli, et al., 2000). The prevailing theory for CVL formation is a 'hotline' caused by convective mantle upwelling (Meyers, et al., 1998; Marzoli, et al., 2000). Truncation of shallow-marine reflections (Fig. 6A) suggests continental up-warping in the study area at this time, as widely reported in the literature (Turner, 1995; Meyers et al., 1998).

Deep-water erosion associated with this uplift rendered the smooth, aggrading Paleogene continental slope (Fig. 9B) into a rugose surface (Fig. 9C). The locations of Cretaceous canyons and canyon-margin slides strongly influenced the location and initial development of various Benito canyons and gullies. All three Cretaceous canyons (northern, central, and southern) were re-activated (Fig. 9C), forming the BNorth, B-Central, and B-South canyons, respectively. Canyons also developed over 
negative seafloor topography created by relict canyon-margin faults (Figs. 6B, 9B-D), notably the slope-parallel tributary that connects the B-North and B-Central canyons (Fig. 9E). Two other examples of fault-related canyon and/or gully development are the parallel E-W trending canyons in the northern study area (Figs. 9B, C). Still other canyons were formed from relatively flat seafloor with no apparent underlying feature, notably the two parallel canyons adjacent to the B-South canyon (Fig. 6B, 9D).

\subsection{Benito canyon system: evolution}

\subsubsection{Persistence of the ancestral Cretaceous canyon topography}

Horizon 4 (16.5 Ma) shows the fully developed B-North, B-central, and B-South canyons and the other subsidiary canyons (Fig. 9D). The relict topography of the central Cretaceous canyon remained active as the B-Central canyon until the deposition of Horizon 5 (Fig. 9E). Subsequently, this canyon was abandoned and began to infill, but is still evident on the modern seafloor (Figs. 4, 9I). Other evidence of the relict Cretaceous canyon system topography on the modern seafloor is the east-west trending abandoned canyon in the northern study area (Figs. 4, 9I) that overlies a Cretaceous canyon-margin fault visible in Horizons 1 and 2 (Figs, 9A, B). This canyon also has not been completely infilled, possibly due to overbank flow from the B-North canyon (Fig. 9I).

Although these features indicate the gradual abandonment of the ancestral Cretaceous canyon topography, some areas of the seafloor have remained sites of 
canyon occupation since the Late Cretaceous. The B-North, B-Central, and B-South canyons overlie the ancestral northern, central, and southern Cretaceous canyons, respectively (Fig. 9). These canyons have remained as topographic features on the seafloor for more than 80 million years. However, the canyon morphology has changed significantly from rough, erosional, and fault-bounded to smooth and aggradational (Fig. 9). The sinuosity has also significantly increased (Figs. 9D-I), presumably due to widespread intra-canyon CLAP deposition and overall slope progradation.

\subsubsection{Canyon relief growth}

The canyon relief grew in early stages by the construction of the inter-canyon areas rather than by erosion of the canyon thalwegs, similar to the process described by Straub and Mohrig (2009). Young, shallow canyons (Figs. 9C, D) may have focused flows, preventing the deposition of CREs or causing minor erosion. As a result, the inter-canyon areas aggraded more rapidly, and the canyons deepened. Deeper canyons were able to capture increasingly larger flow volumes, causing the thinning of the overbank flow in the inter-canyon areas. Eventually, the decreased sedimentation in the inter-canyon areas and increased deposition in the canyons created a dynamic balance so that the rates of aggradation were equal in both areas. This balance has apparently allowed the canyon thalwegs and the inter-canyon areas to aggrade at the same rate (Figs. 4, 6B, 8) after initial canyon deepening. One assumption of this process 
is that the initial flow size and thickness have remained relatively constant through time, which is justified by the stability of canyon morphology since 23 Ma.

\subsubsection{Canyon abandonment}

The maintenance of canyon topography seems to be related to the amount of suspended sediment that reaches the canyon heads. The position of a canyon head in relation to other canyon heads, both in an upslope and lateral sense, determines the volume of flows entering that canyon. If a canyon maintains its head with unimpeded access to the shelf edge, then it will remain an active conduit for shelf-generated turbidity currents. If, however, another canyon migrates into a position upslope of that canyon, it will no longer receive flows and thus will be abandoned, a process termed channel piracy (Normark, 1970b). We infer that cut-off canyons do not receive sufficient turbidity currents to remain active and therefore are infilled (cf. Mather, 2000). Lateral canyon head location and the presence of slope parallel tributaries are also important factors in flow capture/piracy.

The abandonment of the B-Central canyon was related to the pirating of flows by the B-North canyon during Horizons 6-9 (Figs. 9F-I). During Horizons 6-9 (Figs. 9F-I), the progressive growth of the slope-parallel southern tributary of the B-North canyon resulted in the piracy, or diversion, of flows from the B-Central to the B-North canyon. This decrease in turbidity current activity in the B-Central canyon resulted in its abandonment by Horizon 7 (Fig. 9G); during this interval the B-North canyon 
progressively grew. The modern B-North canyon (Fig. 9I) is fed by its own tributary and the ancestral B-Central tributary. However, due to the sharp bend of the latter tributary (Fig. 9I), the B-Central canyon probably still receives periodic flows, resulting in a relatively slow abandonment.

The two N-S trending parallel canyons between the B-Central and B-South canyons were also abandoned during Horizons 5-8 (Figs. 7C, 9E-H). These canyons developed from flat seafloor (Fig. 9D) and remained active until after deposition of Horizon 5 (Fig. 9E) due to flows sourced from the B-South canyon. The buildup of the northern wall of the B-South canyon seen in Horizon 6 (Fig. 9F) shut off the only source of flows to the two parallel canyons. Because the canyon heads did not have direct upslope access to shelf-generated turbidity currents, they began to infill (Fig. 7C) with CLAPs and CREs and were completely abandoned by Horizon 7 (Fig. 9G). Flows proceeding down the inter-canyon area between the B-Central and B-South canyons apparently encountered these oblique-to-slope canyons and deposited infilling CLAPs. The much faster abandonment of these canyons relative to the B-Central is interpreted as a result of their smaller size and deeper position on the slope, reinforcing that lateral and upslope access to turbidity currents is the most important factor in maintaining canyon concavity.

\subsubsection{Canyon-pockmark association}


Pockmarks, first described by King and MacLean (1970), are circular pits on the seafloor usually interpreted to be the product of fluid escape through seafloor sediments, either gas (Hovland and Sommerville, 1985; Charlou et al., 2004; Hovland et al., 2010) or pore-water (Whiticar and Werner, 1981; Harrington, 1985; Hovland et al., 2010). Hovland and Judd (1988) and Hovland et al. (2002) provide a thorough review and size-based classification of pockmarks. Recently, 'trains' of pockmarks have been associated with underlying and dewatering submarine channels (Gay et al., 2003, 2006a, 2006b; Heinio and Davies, 2009).

Numerous pockmark trains overlie abandoned submarine canyons in the study area (Fig. 9), and three stages of pockmark development exist (Figs. 10, 11), each of which is demonstrated on the modern seafloor (Fig. 10A):

1) an abandoned canyon with "cross-canyon ridges";

2) a mostly infilled canyon with multiple, coalesced pockmarks; and 3) an aligned 'train' of discrete, circular pockmarks overlying the abandoned canyon. The formation of ridges and intra-canyon topography has been attributed to many processes, including canyon-bank slumping (Posamentier, 2003), sediment wave crests (Heinio and Davies, 2009), and fluid escape (Hovland and Judd, 1988). The Benito canyon system is devoid of slumps, so the ridges do not seem to be related to mass wasting. The ridges in the abandoned B-Central canyon seem to be related to sediment wave crests (Fig. 10A). However, the majority of cross-canyon ridges develop 
from intra-canyon erosional scours and evolve into long-lived seafloor features (Fig. 10B), suggesting a stationary and continuous ridge-building mechanism such as fluid escape. Fluid escape/seepage has been documented to build up ridges of sediment on the seafloor (Savini et al., 2009; Ivanov et al., 2010) similar in morphology to the crosscanyon ridges in the study area. The low amplitudes of the cross-canyon ridges and the absence of 'chimneys' indicate that gas escape is probably not the primary cause of ridge formation. Pore-water seepage is more plausible due to the large amount of hemipelagic mud in the Benito canyon system, which can initially contain up to $80 \%$ seawater (Hedberg, 1926). Compaction of this mud during early burial (Magara, 1976) causes extensive pore-water expulsion that could form seafloor features such as crosscanyon ridges. Intra-canyon fluid escape may be occurring at all stages of active canyon evolution, but ridge formation is suppressed by turbidity current activity prior to canyon abandonment.

The truncation of CREs by HARs, perhaps by erosional cyclic steps (Fig. 9E; sensu Fildani et al., 2006), in canyon thalwegs may provide the initial topography for ridge formation (Figs. 8, 910B) and the associated erosion may provide preferential pathways for migrating water to be expelled. Furthermore, the little sand available in this system is concentrated in the aggradational canyon thalwegs (Fig. 5), providing enhanced permeability and a vertical pathway for escaping fluid. Where canyons are associated 
with underlying canyon-margin slides (Figs. 6B, 8), the fault planes may also act as vertical fluid migration pathways.

The two parallel N-S trending canyons seen in Horizon 5-8 (Figs. 9E-H) evolve through all three stages of canyon abandonment. Down-canyon and across-canyon seismic sections document the pockmark morphology and the progressive canyon abandonment (Figs. 10B-C). Active-canyon HAR deposition at Horizon 5 (Fig. 9E) truncates CREs, perhaps by erosional cyclic steps. Cross-canyon ridges, Stage 1, develop from these erosional features in the two parallel canyons shown on Horizon 6 (Fig. 9F). During Stage 2 of canyon abandonment, the infilling of much of the canyon results in a shallow linear depression punctuated by ridges and pockmarks (Figs. 10, 11). The ridges grow in relief and form the boundaries between coalesced pockmarks during Stage 2 (Figs. 10B-C, 11). Circular pockmarks are discernible in Stage 2, but usually are paired and not fully developed (Fig. 11). The further infilling of the canyon and pockmark growth characterizes Stage 3, where discrete, circular pockmarks are aligned in a train over the ancient canyon axis (Figs. 10C-D, 11). Pockmarks in Stage 3 are fully developed and circular, averaging $400 \mathrm{~m}$ wide and $60 \mathrm{~ms}(45 \mathrm{~m})$ deep. The development of these pockmarks in predictable locations based on the ridge locations demonstrates that there is a continuous evolution from ridges to pockmarks (see arrows in Fig. 11). 
During initial abandonment, upward pore-water escape is thought to be responsible for cross-canyon ridge formation. Mud entrained by the migrating water may be deposited as ridges on the seafloor adjacent to the site of expulsion. Because these ridges lie adjacent to the site of expulsion, they form the flanks of pockmarks, and the site of water expulsion forms the pockmark center (Fig. 11). Thus, pore-water escape is also thought to dominate the formation of pockmarks in the study area (Cf. Hovland et al., 2010). The pockmark trains directly overlie the ancient canyons (Fig. 10D) because the Benito canyon system is predominantly aggradational in nature (Fig. $6 \mathrm{~B})$ and the dominant direction of fluid migration and escape through sediment is upward (Magara, 1976). Pilcher and Argent (2007) interpret pockmarks in the study area as precursors to submarine canyon formation, rather than representing abandoned canyons. The observations provided by this study seem to suggest that the model of Pilcher and Argent (2007) is incorrect. Furthermore, the evolution from canyons to pockmarks, as documented here, is validated by studies further south on the West African margin (Gay et al., 2003, 2006a, 2006b) and also on the Brazilian margin (Heinio and Davies, 2009).

\section{Discussion}

\subsection{Prograding submarine canyons}

Most studies of canyon evolution document the upslope movement of the head due to mass wasting and downslope-eroding flows (McGregor et al., 1982; Twichell and 
Roberts, 1982; Farre et al., 1983; Pratson et al., 1994). However, this study documents canyon heads that prograde (Fig. 9), a previously undocumented feature. The shelf edge in the study area has prograded a distance of approximately $2 \mathrm{~km}$ since the deposition of Horizon 7, a period of about 5 million years (Fig. 6A). During this time, the B-North and B-South canyon heads have also prograded the same distance, shown in Horizons 7-9 (Figs. 9G-I). The canyons are in equilibrium with the margin, prograding with the margin rather than incising it, suggesting that the Benito canyon system is an equilibrium depositional system (sensu Ross et al., 1994; Pyles et al., this issue) dominated by hemipelagic deposition. This interpretation is supported by the lack of mass wasting and the strictly constructional nature of the margin and canyon system.

\subsection{Sediment supply for the Benito canyon system}

The Rio Muni Basin occupies a low sediment supply area of the West African margin. There are no major river drainages and a narrow $(18 \mathrm{~km})$ shelf (Fig. 2). However, high concentrations of suspended sediment are provided to the basin (Emery et al., 1974) by nearby rivers and coastal currents (Fig. 2). This suspended mud is deposited by hemipelagic deposition in the study area, forming CREs that drape and aggrade the entire slope (Fig. 6). More than $800 \mathrm{~m}$ of aggradation in the Benito canyon system since its inception $\sim 23$ million years ago provides a minimum non-decompacted sedimentation rate of $3.4 \mathrm{~cm} / \mathrm{ky}$, or $34 \mathrm{~m} / \mathrm{Ma}$. Hemipelagic deposition rates on 
continental margins with little terrigenous input average $2 \mathrm{~cm} / \mathrm{ky}$ while highly productive areas average 10-40 cm/ky (Nelson, 1990; Stow et al., 2001). The Benito canyon system is similar to that of a low sediment supply margin dominated by hemipelagic deposition (i.e., $\sim 2 \mathrm{~cm} / \mathrm{ky}$ ), and the additional influx of sediment is attributed to periodic turbidity currents. In contrast, submarine canyon systems in areas of high sediment supply are dominated by turbidity current deposition and have sedimentation rates of 100 to $>1000 \mathrm{~cm} / \mathrm{ky}$ (Damuth and Kumar, 1975; Drake et al 1978; Thornton, 1984; Nelson, 1990; Huh et al., 2009).

\subsection{Initiation mechanisms for turbidity currents in the Benito canyon system}

The most common initiation mechanism for turbidity currents in Type I submarine canyons is the failure of sediment accumulating in a canyon-head (Shepard and Emery, 1973; Keller and Shepard, 1978; Shepard, 1981; Paull et al., 2003) or by canyon head or bank failure (Shepard, 1981; Pratson et al., 1994; Pratson and Coakley, 1996; Armitage et al., 2010). However, the smooth canyon morphologies and lack of shelf-edge collapse features or slump scars in canyon heads (Figs. 1, 4) of the Benito canyon system suggests that the majority of flows were not initiated by mass wasting processes. Furthermore, coarse-grained sediment cannot accumulate in the heads of Benito canyons due to their deep-water location.

Consequently, another process is required to move sediment from the shelf to the heads of the Benito canyon system. Fair weather wave action is generally insufficient to 
re-suspend shelfal sediments, but storm-related waves and increased runoff from local rivers can drastically increase suspended sediment concentrations in shelf waters along wide areas of a continental margin (Moore, 1969; Snedden et al., 1988). This suspended sediment commonly advects offshore to the shelf edge (Moore 1969; Thornton, 1981, 1984; Gorsline et al., 1984), where it can plunge due to excess density (Kassem and Imran, 2001). The result is a thick, dilute turbidity current (Moore, 1969; Shepard et al., 1977; Wright et al., 1988; Peakall et al., 2000; Wynn et al., 2000; Straub and Mohrig, 2009) that is widespread along the margin due to initiation by storm waves and increased local river runoff. These currents may occupy many canyons simultaneously due to their wide, up to $25 \mathrm{~km}$, extent (Stow and Bowen, 1980, Straub and Mohrig, 2009). These currents are most likely responsible for the formation of CLAPs and sediment waves and the maintenance of Benito canyon concavity (Figs. 4, 7D).

In the Rio Muni Basin, high river discharge and resuspension of shelf muds during seasonal storm events may provide the suspended sediment necessary to create thick, dilute, low-density turbidity currents that move downslope in the Benito canyon system. These dilute currents must be able to maintain vigor over the uppermost slope, as they do not enter confinement until $280 \mathrm{~m}$ water depth (Fig. 4). Once the flows reach the canyon heads, they preferentially occupy the canyons, depositing CLAPs and modifying CREs on the outer/downslope bends. Minimum flow thickness must be at least $150 \mathrm{~m}$ in order to deposit the observed CLAPs on the modern seafloor (Fig. 7). The 
flows, if thicker than the canyons, may also occupy the inter-canyon areas (cf. Straub and Mohrig, 2009). The sediment resuspended by these storms not evolving into turbidity currents would be advected to the slope and deposited by hemipelagic deposition, providing a mechanism for CRE deposition. Major storms combined with sea-level low-stands probably explain the periodic, widespread development of sandy HARs (Figs. 5, 8) and the implied robust turbidity currents that deposited them within the Benito canyons. Lower relative sea level may not have exposed the canyon heads, but simply brought the shelfal sediment sources closer, allowing more and coarsergrained sediment to be swept into the canyons.

\subsection{Downdip morphology of the Benito canyon system}

Figure 1 shows the termination of the Benito canyons near the base of slope, and no associated sediment apron/fan is apparent. Pockmark trains extending from the canyon terminations indicate that canyons once extended onto the base of slope, but are now abandoned and infilled (Fig. 1). It is evident that the dilute turbidity currents maintaining the canyons on the steep upper and mid slope are not able to do so on lower slopes. As the flows encounter the reduced slope approaching the basin floor, they slow and become increasingly depositional, leading to the infilling of the canyons (Fig. 1). Because these flows do not carry appreciable quantities of coarse sediment into deep-water, the fine sediment is deposited widely over the seafloor and there is little build up of a submarine fan or apron (Fig. 1). Furthermore, base-of-slope contour 
currents in the area (Emery et al., 1975) may modify or disturb the turbidity currents, similar to the process interpreted by Shanmugam et al. (1993).

\subsection{Contrasting canyon morphologies on the modern seafloor}

The Benito canyon system was formed in the early Miocene and has had a very low supply of sand but an abundant supply of mud, leading to the dominance of hemipelagic deposition in the study area and the formation of a smooth, aggradational canyon system, a shallow slope, and a smooth, muted shelf edge (Fig 1). South of the study area, the morphology of the slope is quite different, with a sharp shelf edge, steep upper slope, and many erosive, shelf-indenting Type I canyons (Fig. 1). The 'Ceiba' canyon (Fig. 1), named for the nearby Ceiba oil field (Dailly et al., 2002) is the most prominent of these canyons. The Ceiba canyon, due to its shelf-indenting head, probably has a much higher coarse-grained sediment supply fed by longshore drift cells. The nearby Mitemele River may also supply coarse-grained sediment to the Ceiba and other erosive canyons (Fig. 2B). The abundant high amplitudes seen in seismic across the Ceiba canyon as well as its erosive morphology and numerous mass wasting features suggest that it is sand-rich and sculpted by erosive turbidity currents. This inference is reinforced by the presence of a large submarine fan downslope of the Ceiba canyon that includes a sinuous, leveed submarine channel (Fig. 1; Coterill et al., 2002). The stark contrast in canyon morphology on either side of the Ceiba canyon and the thinning of the shelf width (Fig. 1) suggests that most sediment supplied via longshore 
drift from the south is captured by the Ceiba and other canyons, resulting in a low coarse-grained sediment supply for the Benito canyon system.

\section{Submarine canyon classification scheme}

\subsection{Type I (Cretaceous, Ceiba) vs. Type II (Benito) canyons}

Based on the comparison of morphology, canyon-fill deposits, and active depositional processes of the canyon systems in the Rio Muni Basin, as well as examples from other continental margins, we suggest the existence of two major groups of submarine canyons, here termed Type I and Type II canyons (Table 1, Fig. 12). Type I submarine canyons have been studied extensively and further subdivided (Kuenen, 1953), while less is known about Type II submarine canyons. Type I canyons indent the shelf edge (Figs. 1, 12; Green and Uken, 2008; Noda et al., 2008; Mountjoy et al., 2009), and canyon heads at times reach to the coastline. Commonly, Type I canyons are associated with high sediment supply, either a fluvial system or longshore drift cell that supplies sand and gravel to the shallow canyon heads (Fig. 12; Inman et al. 1976; O'Connell et al., 1987; Weaver et al., 2000; Covault et al. 2007; Green and Uken, 2008; Yu et al., 2009). They also show V-shaped geometries, numerous tributaries, knickpoints, mass wasting features, and relatively high sinuosities (Figs. 1, 12; Table 1; McGregor et al 1982; Gervais et al., 2004; Bertoni and Cartwright, 2005; Cunningham et al., 2005; Arzola et al., 2008; Lastras et al., 2009). The morphology and evolution of Type I canyons is controlled by sand-rich, erosive turbidity currents and mass wasting 
processes (Table 1; Ericson et al., 1952; Field and Gardner, 1990; Pratson et al., 1994;

Pratson and Coakley, 1996; Weaver et al., 2000; Bertoni and Cartwright, 2005; Yu et al., 2009). Examples of Type I canyon systems in the study area include the modern Ceiba canyon (Fig. 1) and the Cretaceous canyon system (Figs. 8, 9A), both of which display erosive morphologies and coarse-grained fills.

In contrast, shelfal sands are not offered an easy route into Type II canyons due to the water depth (300-700 m) of the canyon heads (Figs. 1, 12; Twichell and Roberts, 1982). Type II canyons typically occur in areas of low sediment supply (Fig. 1) and exhibit morphologies characteristic of low energy deposition, such as aggradation, smooth U-shaped morphologies, and conformable, often draping canyon-fill deposits (Table 1; Figs. 4, 6; Farre et al., 1983). Type II canyon evolution is controlled by depositional processes involving fine-grained sediment that can be carried over the shelf and upper slope into the canyon heads without significant erosion (e.g., Thornton, 1984). Ignitive, sandy, erosive turbidity currents seem to exert little influence on the evolution of Type II canyon systems.

\subsection{Type II canyons: Depositional processes}

Submarine canyons with morphologies similar to Benito canyons have been documented from many margins and may be described as Type II canyons (McGregor et al., 1982; Twichell and Roberts, 1982; Marani et al., 1993; Zhu et al., 2009). The evolution of these canyons has been attributed to various depositional processes (Table 
1). Retrogressive sediment failure (Twichell and Roberts, 1982; Farre et al., 1983) and subsequent headward erosion (McGregor et al., 1982) have been suggested for slopeconfined canyons off New England. Dilute turbidity currents (Stow and Bowen, 1980; Wynn et al., 2000; Straub and Mohrig, 2009) and contour currents (Marani et al., 1993; van Weering et al., 1998; Faugeres et al., 1999) are variably interpreted to construct and maintain some Type II canyons. Most realistically, Type II canyons probably have multiple active depositional processes. Zhu et al. (2009) describes canyons in the South China Sea modified by both turbidity currents and contour currents. This mixed turbidity and contour current regime has also been inferred elsewhere (Howe, 1996; Damuth and Olson, 2001; Viana et al., 2002; Rebseco et al., 2007). Gullies modified by both hemipelagic deposition and turbidity currents are described by Field et al. (1999). The Benito canyon system described by this study is a key example of a Type II canyon system affected by multiple depositional processes, including hemipelagic deposition and the periodic influx of two types of turbidity currents. This unique set of processes and the stability of the West African margin have resulted in the maintenance of submarine canyon topography in the study area for more than 80 million years (Fig. 9).

\section{Application to hydrocarbon exploration}

Type I submarine canyons, including the Cretaceous canyon system in the study area, have long been regarded as hosting highly permeable, sand-rich hydrocarbon reservoirs (Stow and Mayall, 2000; Dailly et al., 2002; Posamentier, 2003). Also, Type I 
canyons are generally associated with downslope submarine fan-channel systems which may be coarse-grained and petroliferous (McHargue and Webb, 1986). In contrast, Type II canyon systems rarely hold hydrocarbons in economic quantities and have no downslope extent, mainly due to their fine-grained nature and low sediment supply. The differing morphologies and architectures of the two canyon types (Figs. 1, 12; Table 1) can aid in making informed pre-drill decisions about reservoir quality in submarine canyon deposits as well as downslope prospectivity.

Type II canyons, although not generally useful for reservoirs, can form seals and/or source intervals. The abandoned Type II Benito canyon system overlies and helps to form the seal to the Okume complex oil field developed in the Type I Cretaceous canyon system (Fig. 9). Type II canyons may also form unconventional reservoirs which, for economic and technological reasons, have yet to be investigated. The abundant organic material deposited by hemipelagic processes (Thornton, 1984) may promote the development of source rock intervals or unconventional reservoirs in Type II canyon systems.

The occurrence of various seafloor features related to Type II canyon systems can aid in the prediction and interpretation of subsurface features. The B-Central canyon on the modern seafloor indicates the presence of the underlying oil-filled Cretaceous canyon. Care must be taken, however, when interpreting these abandoned canyons, as not all overlie sand-rich Type I systems. For example, many partially abandoned 
canyons in the study area indicate abandoned Type II canyons, which have little reservoir potential. Pockmarks on the seafloor have been typically related to gas seepage and can indicate the presence of an active petroleum system (Hovland and Judd, 1988; Hovland et al., 2010). It seems, however, that many pockmarks, such as the ones in this study, are instead related to pore-water escape during compaction, denoting the importance of understanding the underlying stratigraphic architecture and performing geochemical fluid sampling when studying pockmark genesis.

\section{Conclusions}

The low sediment supply Rio Muni Basin on the West African margin has been dominated by various submarine canyon systems for more than 80 million years. The Late Cretaceous canyon system in the study area was relatively sand-rich, shelfindenting, and conveyed erosive turbidity currents downslope, likely to a sand-rich submarine fan. After a quiescent period during the Paleogene, the ancestral canyon topography was re-activated in the early Miocene due to tectonic uplift. The resultant canyon morphologies were drastically different from those of the Cretaceous canyon system. The modern Benito canyon system is muddy, does not indent the shelf edge, and displays smooth, aggradational canyon morphologies indicative of hemipelagic deposition and modification by dilute, sluggish turbidity currents. The maintenance of Benito canyon concavity seems to be related to unimpeded upslope access to shelfgenerated turbidity currents. Where access is lost via canyon piracy, canyons are 
abandoned and infilled in a predictable manner, where fluid escape related to the compaction of hemipelagic mud generates pockmarks trains overlying the canyon axes.

The smooth, aggradational Benito canyon system on the modern seafloor contrasts with the adjacent Ceiba canyon, which is coarse-grained, erosional, and morphologically similar to the Cretaceous canyon system. The Ceiba canyon also has a large downslope submarine fan-channel system. Based on the comparison of these three canyon systems as well as other examples, we propose the bipartite division of submarine canyons. 'Type I canyons,' such as the Cretaceous and Ceiba canyons, indent the shelf, have access to coarse-grained sediment, and build large downslope submarine fan-channel systems. Ignitive, erosive, sand-rich turbidity currents sourced from shallow water and mass wasting processes in Type I canyons produce V-shaped profiles, intra-canyon slumps, terraces, and sand-rich canyon fill. 'Type II canyons,' such as the Benito canyon system, head in deep water and therefore lack access to coarse-grained sediment. Type II canyons have low sediment supply and therefore no associated downdip sediment apron. Their morphologies are consistent with low energy deposition, including smooth, $\mathrm{U}$ shaped canyons and conformable, mud-rich canyon fill. Hemipelagic deposition and dilute turbidity currents are the chief depositional processes in the Benito canyon system, and other Type II canyons are influenced by various processes depending on local conditions. Erosive turbidity currents seem to be rare and relatively unimportant in Type II canyon evolution. It is 
hoped that this canyon classification scheme can aid in elucidating depositional processes and the evolution of submarine canyon systems on any continental margin.

\section{Acknowledgments}

We would like to thank first and foremost the generosity of Hess Corporation for the release of seismic, well, and core data and also for the donation of computer workstations to ZRJ. Jim Hewlett, Michele Simon, Robin Pilcher, and many others at Hess were instrumental to the success of this project. We also recognize Hess's partners, GEPetrol and Tullow Oil, Plc., and the MMIE (Ministry of Mines, Energy, and Industry) of the Republic of Equatorial Guinea for the release of data. Paradigm B.V. graciously donated software for the data interpretation and we must thank Scott Miller, Yuyu Wang, Carmen Comis, and Charmaine Bixler for their support. We also acknowledge Marshall Pounds and Fugro, who donated and shipped core samples. We would also like to thank the member companies of the Stanford Project On Deepwater Depositional Systems (SPODDS) industrial affiliates program for funding ZRJ's graduate research at Stanford University. These companies include: Aera, Anadarko, Chevron, ConocoPhillips, Devon, ENI-AGIP, ExxonMobil, Hess, Marathon, Nexen, Occidental, PetroBras, Reliance, Repsol-YPF, Rohöl-Aufsuchungs AG (R.A.G.), and

Shell. The Department of Geological and Environmental Sciences at Stanford University also provides additional financial support through fellowships and teaching assistantships. We are also grateful for the many perceptive discussions and comments 
from Bill Morris, Jim Hewlett, Gary Parker, Mike Field, Charlie Paull, Mary McGann, Jed Damuth, Victor Vega, and SPODDS geologists Dominic Armitage, Anne Bernhardt, Jake Covault, Julie Fosdick, Katie Maier, Larisa Masalimova, Chris Mitchell, Brian Romans, Jon Rotzien, and Lisa Stright. Finally, we would like to express many thanks to Russell Wynn and Mangzheng Zhu, whose acute reviews greatly improved this manuscript. 


\begin{tabular}{|c|c|c|}
\hline Query & Type I canyons & Type II canyons \\
\hline $\begin{array}{l}\text { Shelf edge indentation/ } \\
\text { Canyon head location }\end{array}$ & Indent the shelf edge & Do not indent the shelf edge \\
\hline Sediment supply & $\begin{array}{c}\text { High; commonly associated with a } \\
\text { large fluival system or longshore } \\
\text { drift cell }\end{array}$ & $\begin{array}{c}\text { Low; not adjacent to major river } \\
\text { drainages }\end{array}$ \\
\hline $\begin{array}{c}\text { General slope } \\
\text { morphology }\end{array}$ & $\begin{array}{c}\text { Sharp shelf edge and steep upper } \\
\text { slope }\end{array}$ & $\begin{array}{c}\text { Muted shelf edge and shallow } \\
\text { upper slope }\end{array}$ \\
\hline Sinuousity (in general) & $\begin{array}{l}\text { Highly sinuous (>2); bend geometry } \\
\text { is predictable }\end{array}$ & $\begin{array}{c}\text { Less sinuous }(<2) \text { to straight; makes } \\
\text { unpredictable bends }\end{array}$ \\
\hline $\begin{array}{c}\text { Cross-sectional } \\
\text { geometry }\end{array}$ & V shape with terraces & U shape, flat bottom \\
\hline Geometrical complexity & Tributaries, pinnate patterns & Simple, single canyons \\
\hline Depositional style & Erosional & Aggradational/Constructional \\
\hline $\begin{array}{l}\text { Depsitional processes, } \\
\text { in descending } \\
\text { importance }\end{array}$ & $\begin{array}{l}\text { Turbidity current } \\
\text { erosion/deposition; mass wasting }\end{array}$ & $\begin{array}{c}\text { Hemipelagic deposition; dilute } \\
\text { turbidity current deposition; } \\
\text { bottom current deposition; mass } \\
\text { wasting processes }\end{array}$ \\
\hline Intra-canyon features & $\begin{array}{c}\text { Terraces; scalloped margins; } \\
\text { discontinuous, erosive features }\end{array}$ & $\begin{array}{c}\text { Smooth, draping deposits; lateral } \\
\text { accretion deposits }\end{array}$ \\
\hline $\begin{array}{l}\text { Grain size: Canyon fill } \\
\text { and inter-canyon areas }\end{array}$ & $\begin{array}{c}\text { Sand and grave; mud clast } \\
\text { conglomerate; sandy/muddy inter- } \\
\text { canyon areas } \\
\end{array}$ & $\begin{array}{c}\text { Hemipelagic clay; traction } \\
\text { structured silt; sand(?); muddy } \\
\text { inter-canyon areas } \\
\end{array}$ \\
\hline Downdip expression & $\begin{array}{l}\text { Large, coarse-grained submarine } \\
\text { fan-channel system }\end{array}$ & $\begin{array}{c}\text { Canyons die out at base of slope } \\
\text { and have no associated sediment } \\
\text { apron }\end{array}$ \\
\hline $\begin{array}{l}\text { Notable modern } \\
\text { seafloor examples }\end{array}$ & $\begin{array}{c}\text { Zaire/Congo; Mississippi; } \\
\text { Monterey; Eel, CA; Var; Bay of } \\
\text { Biscay }\end{array}$ & $\begin{array}{c}\text { Rio Muni; Eel, CA; Gabon; New } \\
\text { Jersey; Faeroes; South China Sea; } \\
\text { Ebro }\end{array}$ \\
\hline Examples in this study & $\begin{array}{c}\text { Ceiba canyon; Cretaceous canyon } \\
\text { system }\end{array}$ & Benito canyon system \\
\hline
\end{tabular}


Figure 1. Comparison of submarine canyon morphologies and their downslope evolution, shown by a time structure map of the modern Equatorial Guinean seafloor. The stark contrast between canyon morphologies south of and north of the Ceiba canyon results from differing sediment supply. In the south, high sediment supply forms steep slopes and shelf-indenting, sand-rich Type I canyons with erosive morphologies and downslope submarine fans. The capture of sediment by the Type I Ceiba canyon starves the area to the north, where the Type II Benito canyon system is developed. The low sediment supply creates shallower slopes and Type II canyons, which have smooth, aggradational morphologies, no shelf-edge indentation, mud-rich fill, and no downslope sediment accumulation. White box in inset photo is the location of the study area (see Fig. 2). 


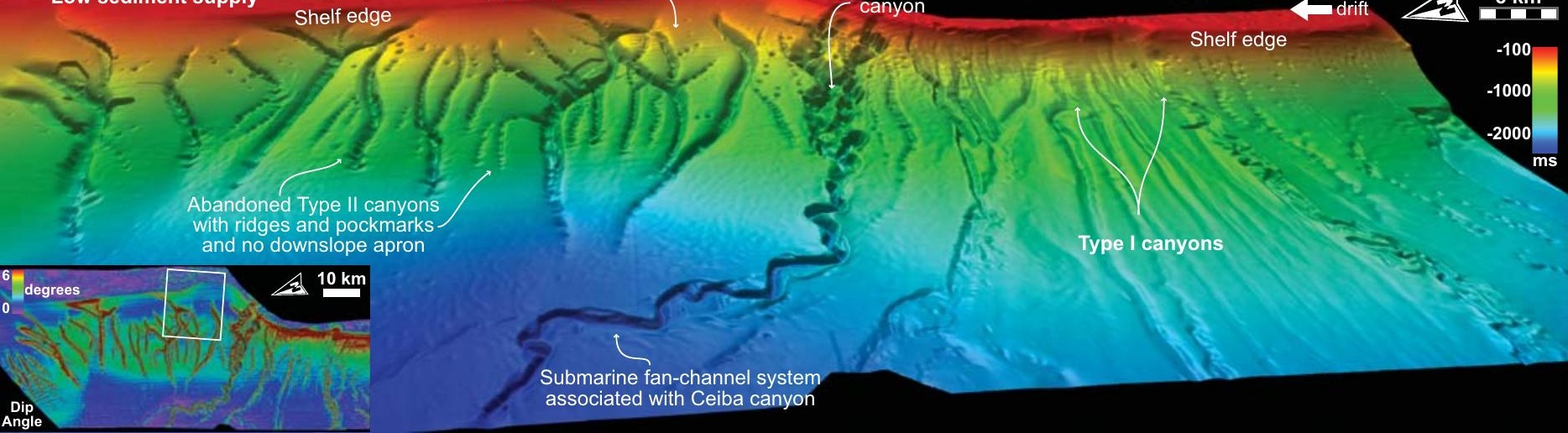




\section{Figure 2. Location of the Benito canyon system.}

(A) The Gulf of Guinea and the Rio Muni basin, an obliquely sheared rift basin associated with the Ascension fracture zone. Major rivers are labeled and modern wind (orange arrows) and longshore drift (pink arrows) are indicated. Muddy river plumes from the south drift northward into the study area and coarse-grained sediment is provided by local rivers and northbound longshore drift.

(B) Offshore Equatorial Guinea, denoted by black rectangle in (A). Orange shading indicates African craton while unshaded area indicates onshore Rio Muni basin sediments. The extent of Figure 1 is shown by the high resolution bathymetry and the study area is indicated by a black rectangle. Note the narrow shelf, variably indented shelf edge, and location of the Benito and Mitemele rivers. Compiled from Burke, 1972; Emery et al., 1974; Servain et al., 1985; Mariano et al., 1995; Meyers et al., 1996; Jourdin et al., 2006. 
Figure 3. Stratigraphic evolution of the Rio Muni Basin. The Cretaceous canyon system was erosive and sand-rich. The Paleogene was a time of quiescence, when the canyon system aggraded via hemipelagic deposition. The early Miocene reorganization of the margin during basin-wide tectonism led to the initiation of the modern Benito canyon system, a muddy and aggradational canyon system. The upward decrease in sand and canyon margin faulting is likely related to changes in sediment supply. Note the transitional crust underlying the basin, a result of the sheared, extended nature of the margin. CVL - Cameroon Volcanic Line. Modified from Turner (1995) and Meyers et al (1996). 


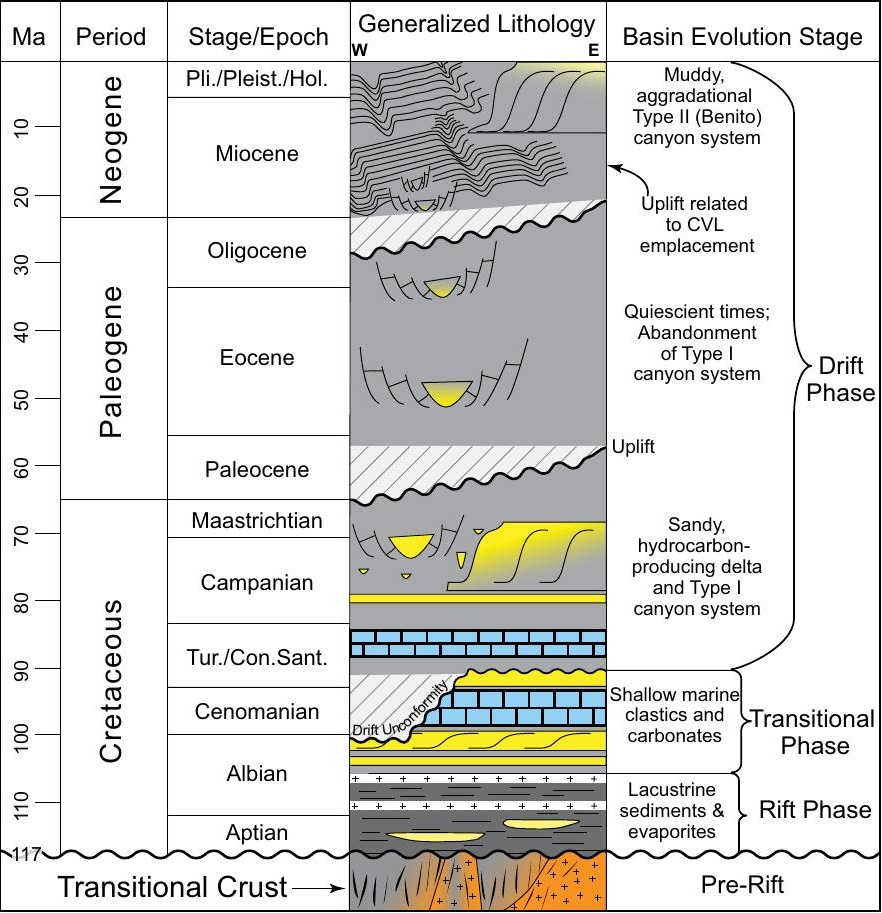


Figure 4. Time structure diagram of the seafloor derived from the $400 \mathrm{~km}^{2} 3-\mathrm{D}$ seismic reflection dataset used in this study. View is to the southeast. The " $U$ " shaped canyons head in water $\sim 280 \mathrm{~m}$ water depth and show smooth morphologies. The seismic crosssection demonstrates the aggradational nature of the margin. The active "B-North" and "B-South" canyons and the abandoned "B-Central" canyon on the modern seafloor are labeled and the thalwegs identified with a thin black line on the inset. Abandoned canyons are denoted on the seafloor by pockmark trains in various stages of development. 


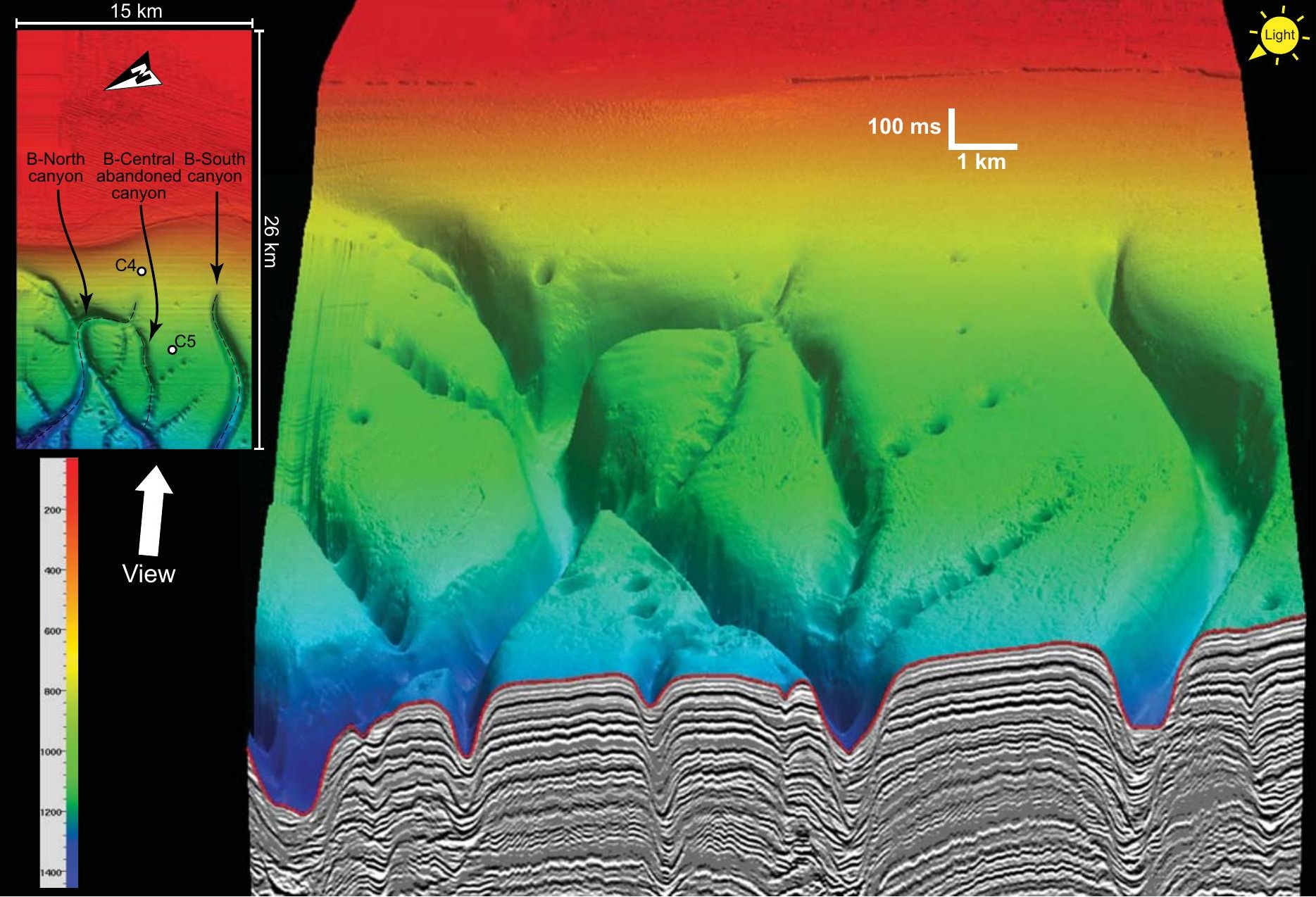


Figure 5. RMS (root mean square) amplitude map of the seafloor and shallow subsurface cores. Canyon thalwegs are filled with high-amplitude reflection elements (HARs), suggesting coarse-grained deposition via turbidity currents. The inter-canyon areas consist of low amplitude conformable reflection elements (CREs) that are demonstrably muddy in cores C4 and C5. Shelfal cores contain various amounts of sand related to the coastal northbound longshore drift; this sand is likely the source for the HARs. 


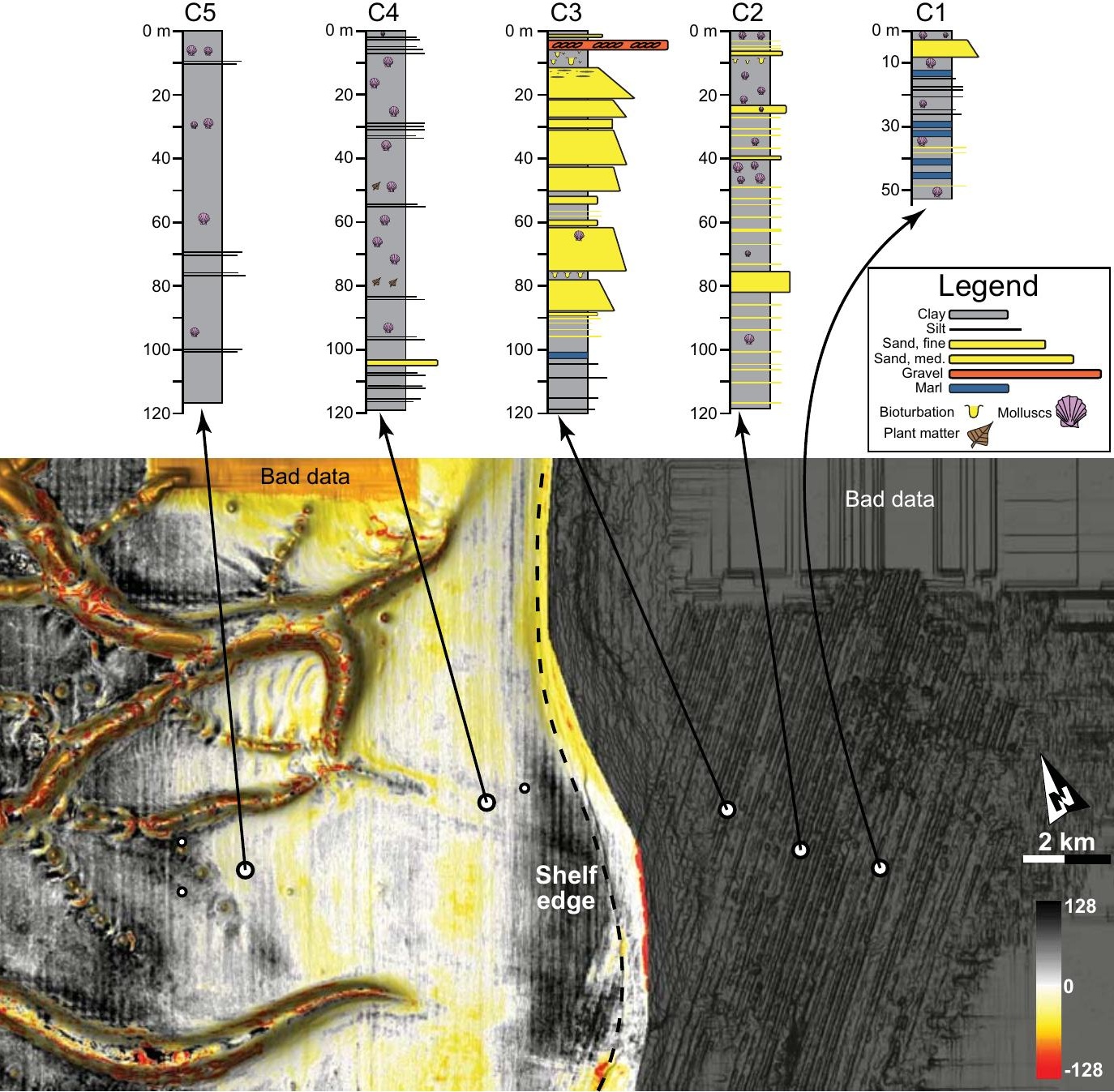


Figure 6. Seismic reflection profiles of the Benito canyon system.

(A) A dip profile shows the aggradational and slightly progradational character of the margin. CREs, deposited by hemipelagic deposition, comprise the majority of the study area. The C 5 core demonstrates that these CREs are composed predominantly of clay. Horizons 1-9 are also shown; Horizon 3 (23 Ma) is the initiation of the Benito canyon system.

(B) A strike profile displays the two active B-North and B-South canyons as well as the abandoned B-Central canyon that overlie the ancestral Cretaceous canyons. The Benito canyon system has aggraded more than $800 \mathrm{~m}$ since its inception at Horizon 3. Note the vertical to off-vertical canyon trajectories, indicating little to no migration during aggradation. Canyon-margin faulting/sliding identified in pink was related to the underlying Cretaceous canyon system, but does not affect the modern Benito canyon system. 

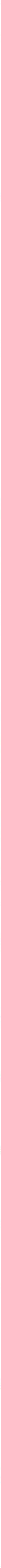
Figure 7. CLAP (canyon lateral accretion packages) elements, which are deposited by thick, dilute, low-density turbidity currents.

(A) and (B) show the modern seafloor, where the low sinuosity (1.07) B-South canyon and the CLAPs associated with its meandering. The direction of accretion is always towards the outer bend of the canyon, indicating downslope directed turbidity currents. The canyon trajectory is slightly migrational in the direction of the CLAPs - right to left in (A) and left to right in (B).

(C) CLAPs in the subsurface, where two straight, slope-oblique canyons in Horizon 5 (teal line and inset) display accretion downslope. Thick, dilute turbidity currents flowing downslope encounter these canyons and deposit mud on the upslope bank and erode the downslope bank.

(D) CLAPs in the modern B-North canyon, showing inner- to outer-bend accretion and the presence of sediment waves adjacent to the outer bend, indicating flow-stripping of dilute turbidity currents. Horizon 8 is shown by the dashed line and inset map. 
Figure 8. Thalweg HAR elements, deposited by erosive turbidity currents. The HARs are concentrated in the thalwegs of the canyons and are stacked on and truncate each other, indicative of flows able to erode locally the beds over which they moved. The temporal correlation of HARs, notably between Horizons 5 and 6, may be related to a period of coarse-grained sediment influx into the basin. Note the location of the Cretaceous canyons and the evolution of that topography into the modern Benito canyons. 


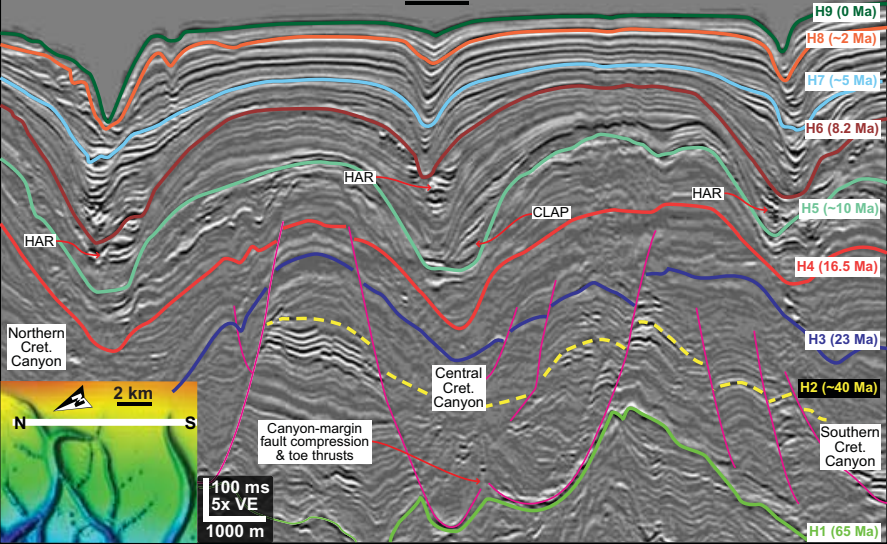


Figure 9. Benito canyon system evolution. Hot and cool colors on these time structure maps represent topographic highs and lows, respectively.

(A) - (B) Horizons 1 and 2 shows the ancestral Cretaceous canyon system and the associated canyon margin faults. Note the locations of the northern, central, and southern Cretaceous canyons.

(C) - (D) Horizons 3 and 4 are the initiation and early development of the Benito canyon system, related to erosion and uplift associated with emplacement of the Cameroon volcanic line. Note the re-activation of the ancestral Cretaceous canyon topography, forming the B-North, Central, and South canyons.

(E) - (F) Horizons 5 and 6 show the migration of the B-North canyon head above the BCentral canyon, causing the abandonment of the B-Central canyon due to loss of upslope flow access. Note the infilling of the canyon from Horizons 5 to 7.

(G) - (I) Horizons 7-9 exhibit the development of the modern seafloor and the progradation of the canyon heads along with the shelf edge. Also, the two parallel canyons adjacent to the B-South canyon are abandoned in this interval, leading to the formation of cross-canyon ridges and pockmark trains overlying the canyons. 


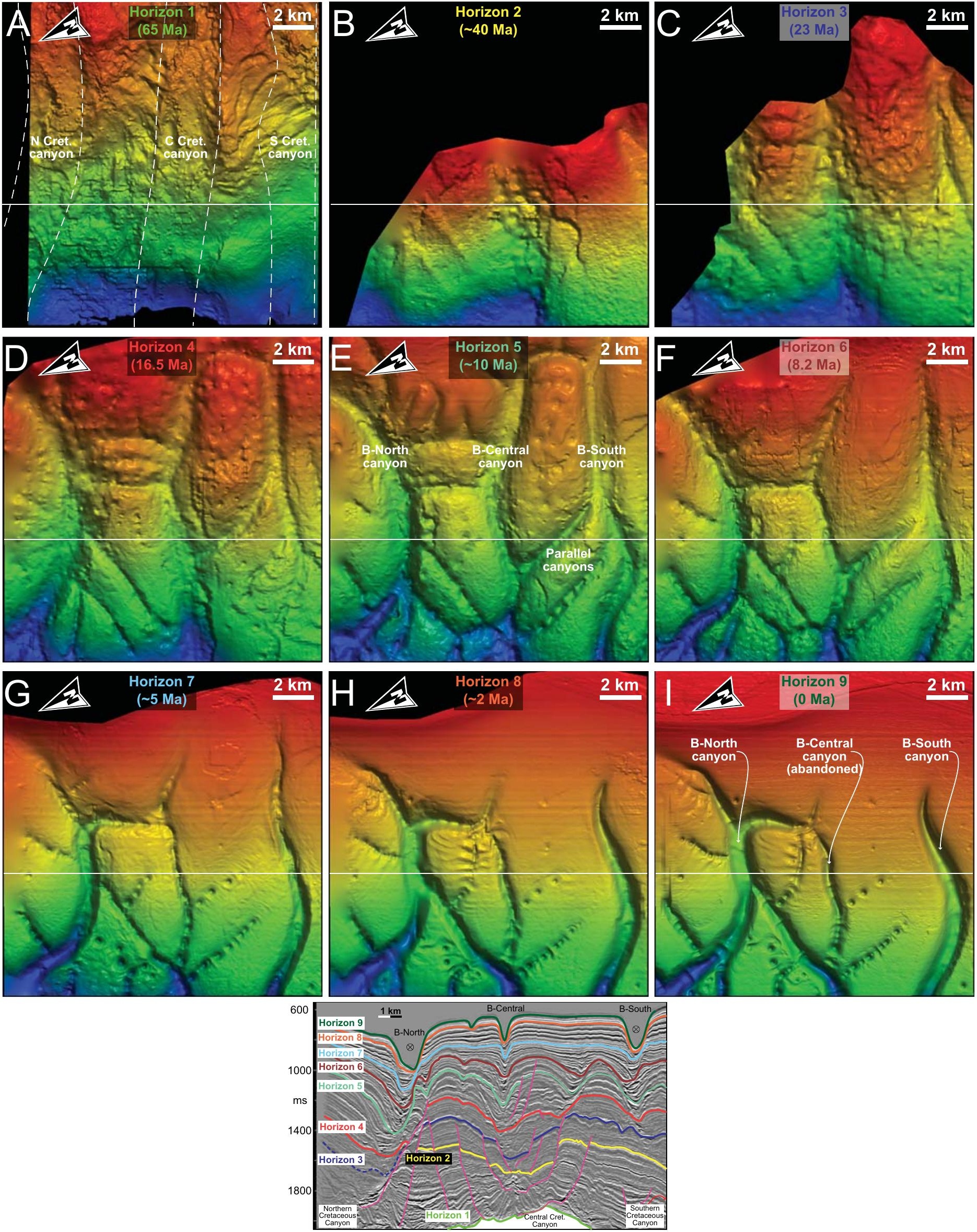




\section{Figure 10. Pockmark association with Benito canyons.}

(A) The modern seafloor documents canyons in all three stages of abandonment, and the numbers correspond to these stages: 1 - cross-canyon ridges in an abandoned canyon; 2 - thinning canyon with ridges and coalesced pockmarks; and 3 - discrete, circular pockmarks aligned in a train above the abandoned canyon. The central Cretaceous canyon displays Stage 1 while the two parallel canyons are in Stages 2 and 3.

(B) Down-canyon seismic section of the lower parallel canyon, documenting the evolution from an active canyon to a pockmark train. Horizon 5 shows the development of HARs and irregular ridges in the canyon, but after Horizon 6 (see Fig. 9F), this canyon was abandoned and filled in with CREs. Note the development of a cross-canyon ridge from a intra-canyon bump, the location of the ridge through time, and the location of pockmarks on its flanks.

(C) Across-canyon seismic section, showing both parallel canyons were abandoned after Horizon 6 and were infilled with CREs. Note the location of the seafloor pockmarks that directly overlie the ancient canyons.

(D) The time structure of the seafloor and the color of Horizon 5 are juxtaposed on each other to demonstrate that pockmark trains and ridge development overlie the axes of abandoned subsurface canyons. 


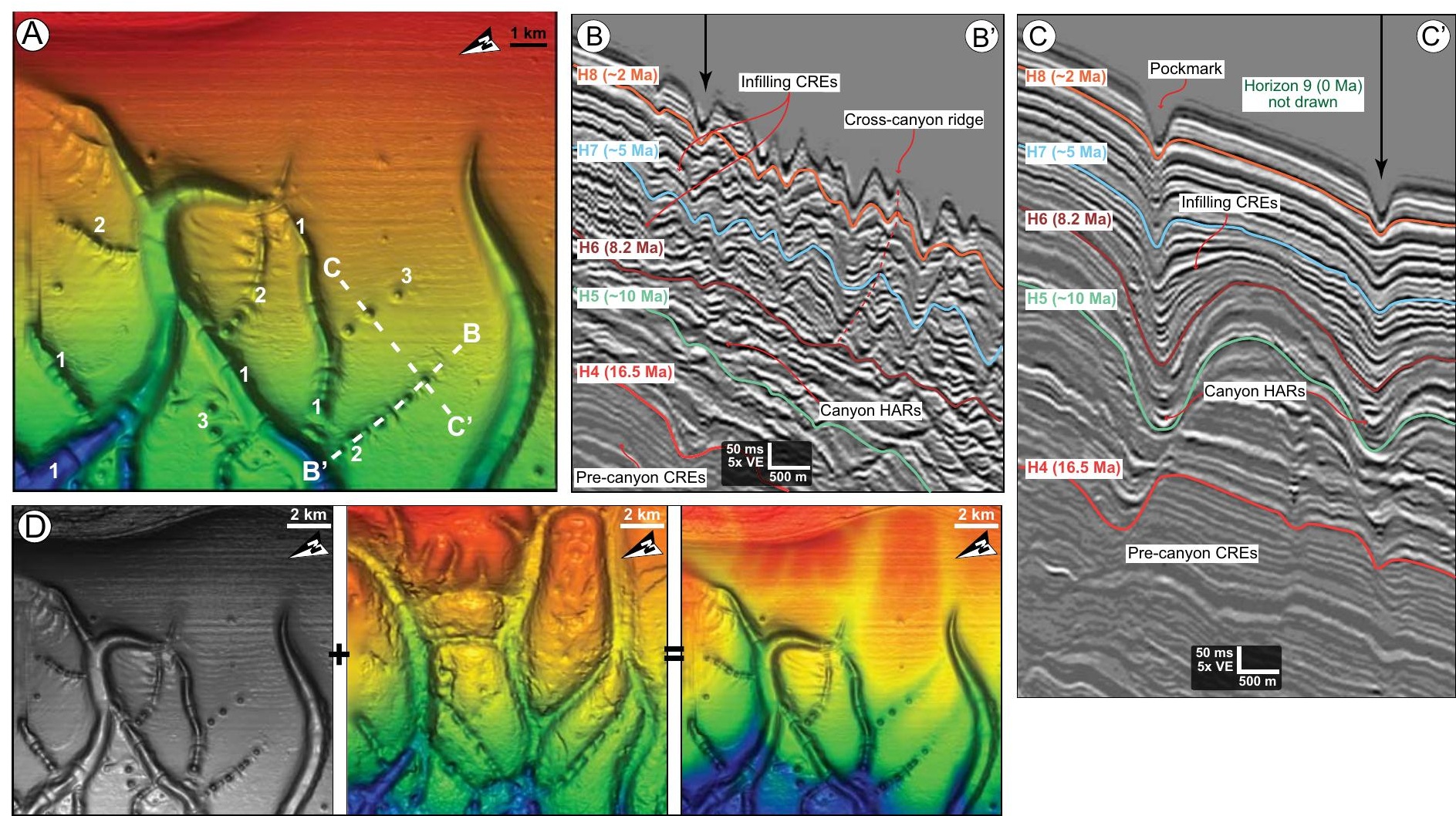


Figure 11. Stages of canyon abandonment. After succumbing to upslope flow capture, an abandoned canyon forms cross-canyon ridges (Stage 1). These ridges develop over small intra-canyon irregularities and are formed by fluid escape from compacting, underlying sediments. The ridges do not move, and form the flanks of pockmarks (see arrows). In Stage 2, the thinning, infilling canyon develops pockmarks, which are located in the lows between the ridges and also related to fluid escape. These pockmarks evolve into a train of discrete, circular pockmarks that overlies the abandoned canyon. 


\section{Active canyon} with unimpeded upslope access

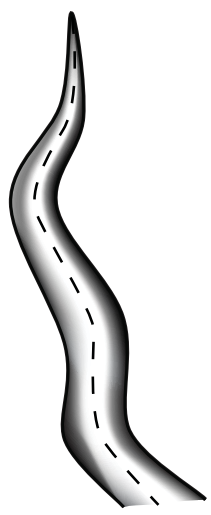

Stage 1

Cross-canyon ridges in a canyon recently abandoned by upslope flow capture
Stage 2

Thinning canyon with ridges and coalesced pockmarks
Stage 3 Discrete pockmarks aligned in a 'train'

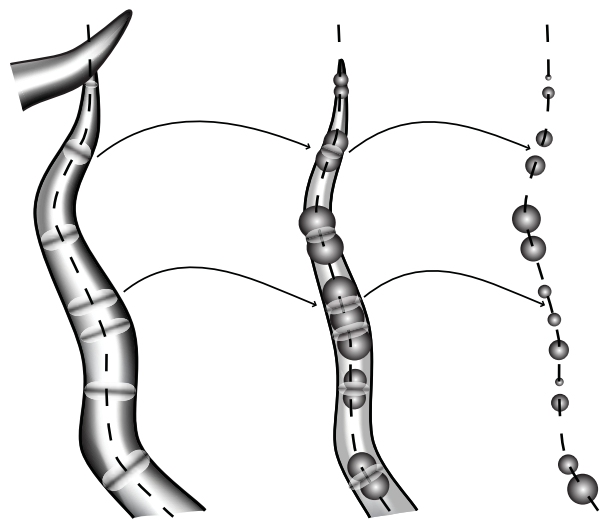


Figure 12. Canyon classification scheme. Type I canyons indent the shelf edge, are sand-rich, associated with high sediment supply, and terminate into a sandy submarine fan. Type II canyons, on the other hand, do not indent the shelf edge, are mud-rich, and have no downdip sediment accumulation due to their location in an area of low sediment supply. It seems that just enough erosion occurs to keep the canyons open, but not enough to generate a downslope sediment apron. 


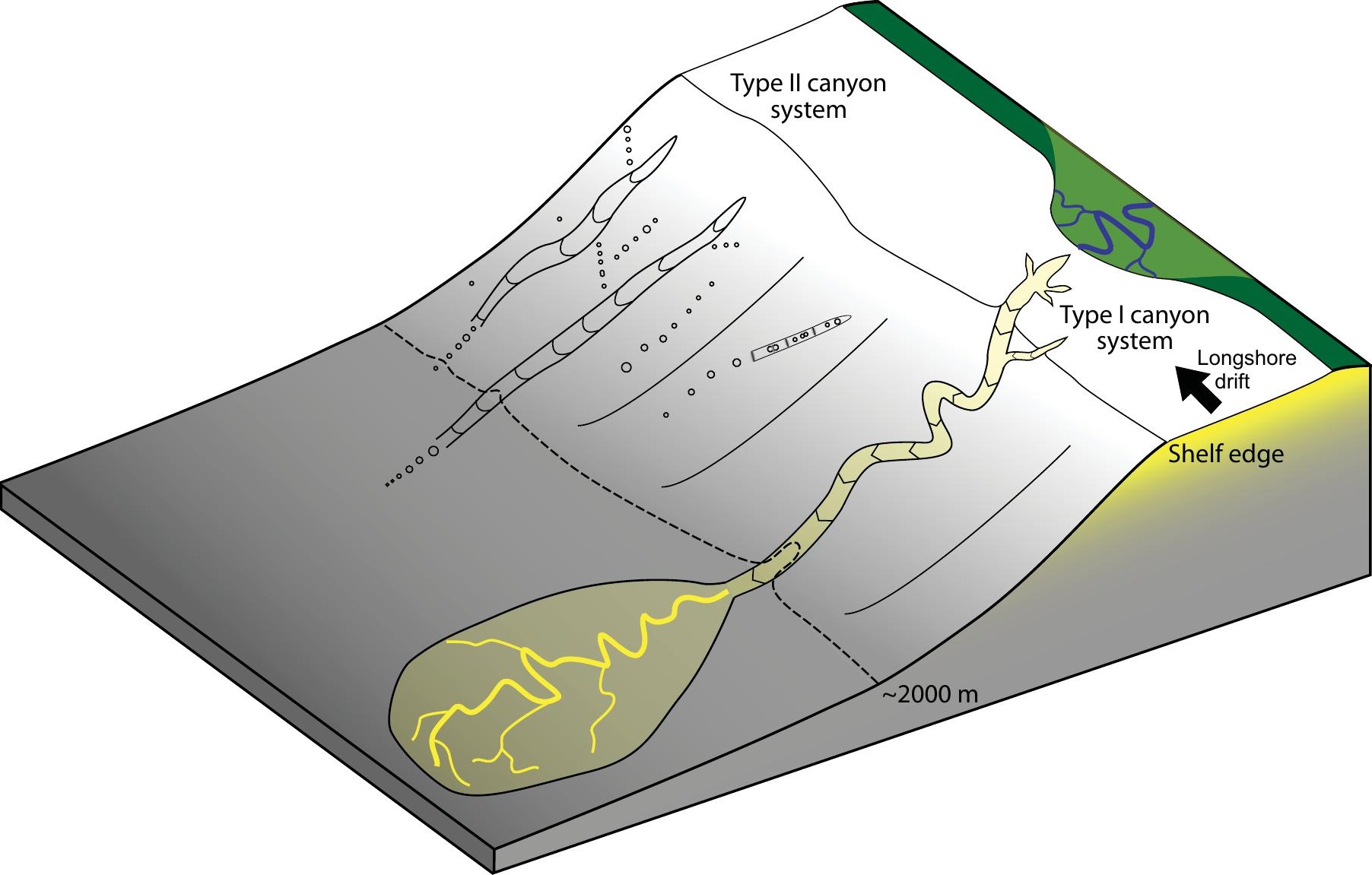




\section{References}

Abreu, V., Sullivan, M., Pirmez, C., and Mohrig, D., 2003, Lateral accretion packages (LAPs): an important reservoir element in deep water sinuous channels. Marine and Petroleum Geology, v. 20, no. 6-8, p. 631-648.

Anderson, K.S., Graham, S.A., and Hubbard, S.M., 2006, Facies, architecture, and origin of a reservoir-scale sand-rich succession within submarine canyon fill: insights from Wagon Caves Rock (Paleocene), Santa Lucia Range, California, U.S.A. Journal of Sedimentary Research, v. 76, p. 819-838.

Antobreh, A.A., and Krastel, S., 2006, Morphology, seismic characteristics and development of Cap Timiris Canyon, offshore Mauritania: A newly discovered canyon preserved-off a major arid climatic region. Marine and Petroleum Geology, v. 23, no. 1, p. 37-59.

Armitage, D.A., Romans, B.W., Covault, J.A., and Graham, S.A., 2009, The influence of mass-transport-deposit surface topography on the evolution of turbidite architecture: The Sierra Contreras, Tres Pasos Formation (Cretaceous), Southern Chile. Journal of Sedimentary Research, v. 79, no. 5, p. 287-301.

Armitage, D.A., Piper, D.J.W., McGee, D.T., and Morris, W.R., 2010, Turbidite deposition on the glacially influenced, canyon-dominated Southwest Grand Banks Slope, Canada. Sedimentology, doi: 10.1111/j.1365-3091.2010.01149.x

Arnott, R.W.C., 2007, Stratal architecture and origin of lateral accretion deposits (LADs) and conterminuous inner-bank levee deposits in a base-of-slope sinuous channel, lower Isaac Formation (Neoproterozoic), East-Central British Columbia, Canada: Marine and Petroluem Geology, v. 24, p. 515-528.

Bertoni, C. and Cartwright, J., 2005, 3D seismic analysis of slope-confined canyons from the Plio-Pleistocene of the Ebro Continental Margin (Western Mediterranean). Basin Research, v. 17, p. 43-62.

Blum, P., and Okamura, Y., 1992, Pre-Holocene sediment dispersal systems and effects of structural controls and Holocene sea-level rise from acoustic facies analysis, SW Japan forearc. Marine Geology, v. 108, p. 295-322. 
Bulat, J., and Long, D., 2001, Images of the seabed in the Faroe-Shetland Channel from commercial 3D seismic data. Marine Geophysical Researches, v. 22, no. 5, p. 345367.

Burke, K., 1972, Longshore Drift, Submarine Canyons, and Submarine Fans in Development of Niger Delta. American Association of Petroleum Geologists Bulletin, v. 56, no. 10, p. 1975-1983.

Charlou, J.L., Donval, J.P., Fouquet, Y., Ondreas, H., Cochonat, P., Levache, D., Poirier, Y., Jean-Baptiste, P., Fourre, E., Chazallon, B., Zairov-Leg 2 Scientific Party, 2004, Physical and chemical characterization of gas hydrates and associated methane plumes in the Congo-Angola Basin. Chemical Geology, v. 205, p. 405-425.

Coterill, K., Tari, G.C., Molnar, J., and Ashton, P.R., 2002, Comparison of depositional sequences and tectonic styles among the West African deepwater frontiers of western Ivory Coast, southern Equatorial Guinea, and northern Namibia. The Leading Edge, v. 21, no. 11, p. 1103-1111.

Covault, J.A., Normark, W.R., Romans, B.W., Graham, S.A., 2007, Highstand fans in the California Borderland: the overlooked deep-water depositional system. Geology v. 35, p. 783-786.

Cronin, B.T., Celik, H., Hurst, A., Gul, M., Gurbuz, K., Mazzini, A., Overstolz, M., 2007, Deep-water slope channel complex fill and overbank architecture of the Tinker Channel, Kirkgecit Formation, Turkey. in Nilsen, T., Shew, R., Steffens, G., and Studlick, J., eds., Deep-Water Outcrops of the World Atlas: American Association of Petroleum Geologists, Studies in Geology 56, p. 363-367.

Cunningham, M.J., Hodgson, S., Masson, D.G., and Parson, L.M., 2005, An evaluation of along- and down-slope sediment transport processes between Goban Spur and Brenot Spur on the Celtic Margin of the Bay of Biscay. Sedimentary Geology, v. 179, p. 99-116.

Dailly, P., Lowry, P., Goh, K., and Monson, G., 2002, Exploration and development of Ceiba Field, Rio Muni Basin, Southern Equatorial Guinea. The Leading Edge, v. 21, p. 1140-1146.

Damuth, J.E., and Kumar, N., 1975, Amazon Cone: Morphology, Sediments, Age, and Growth Pattern. Bulletin of the Geological Society of America, v. 86, no. 6, p. 863878. 
Damuth, J.E., and Olson, H.C., 2001, Neogene-Quaternary contourite and related deposition on the West Shetland Slope and Faeroe-Shetland Channel revealed by high-resolution seismic studies. Marine Geophysical Researches, v. 22, no. 5, p. 369-398.

Deptuck, M.E., Steffens, G.S., Barton, M., and Pirmez, C., 2003, Architecture and evolution of upper fan channel-belts on the Niger Delta slope and in the Arabian Sea: Marine and Petroleum Geology, v. 20, p. 649-676.

Deptuck, M.E., Sylvester, Z., Pirmez, C., and O'Byrne, C.O., 2007, Migrationaggradation history and 3-D seismic geomorphology of submarine channels in the Pleistocene Benin-major Canyon, western Niger Delta slope. Marine and Petroleum Geology, v. 24, p. 406-433.

Drake, D.E., Hatcher, P.G. and Keller, G.H., 1978, Suspended particulate matter and mud deposition in upper Hudson submarine canyon. in Stanley, D.J. and Kelling, G., eds., Sedimentation in Submarine Canyons, Fans and Trenches: Dowden Hutchinson and Ross, Stroudsburg, Pennsylvania, p. 33-41.

Dutta, T., 2009, Integrating Sequence Stratigraphy and Rock-Physics to Interpret Seismic Amplitudes and Predict Reservoir Quality. Ph.D. dissertation, Stanford University, Stanford, California, $194 \mathrm{p}$.

Dykstra, M., and Kneller, B., 2009, Lateral accretion in a deep-marine channel complex: implications for channellized flow processes in turbidity currents: Sedimentology, v. 56, no. 5, p. 1411-1432.

Emery, K.O., Lepple, F., Toner, L., Uchupi, E., Rioux, R.H., Pople, W., and Hulburt, E.M., 1974, Suspended matter and other properties of surface waters of the northeastern Atlantic Ocean. Journal of Sedimentary Research, v. 44, no. 4, p. 1087-1110.

Emery, K.O., Uchupi, E., Phillips, J., Bowin, C.O., and Mascle, J., 1975, Continental margin off western Africa: Angola to Sierra Leone. American Association of Petroleum Geologists Bulletin, v. 59, no. 12, p. 2209-2265.

Ericson, D., Ewing, M., and Heezen, B.C., 1952, Turbidity currents and sediments in North Atalantic. American Association of Petroleum Geologists Bulletin, v. 36, no. 3, pp. 489-511. 
Fan, S., Swift, D.J.P., Traykovski, P., Bentley, S., Borgeld, J.C., Reed, C.W. and Niedoroda, A.W., 2004, River flooding, storm resuspension, and event stratigraphy on the northern California shelf: observations compared with simulations. Marine Geology, v. 210, pp. 17-41.

Farre, J.A., McGregor, B.A., Ryan, W.B.F., and Robb, J.M., 1983, Breaching the shelfbreak: Passage from youthful to mature phase in submarine canyon evolution. SEPM Special Publication, v. 33, p. 25-39.

Faugeres, J.C., Stow, D.A.V., Imbert, P., and Viana, A., 1999, Seismic features diagnostic of contourite drifts. Marine Geology, v. 162, no. 1, p. 1-38.

Field, M.E., and Gardner, J.V., 1990, Pliocene-Pleistocene growth of the Rio Ebro margin, northeast Spain: A prograding-slope model. Bulletin of the Geological Society of America, v. 102, no. 6, p. 721-733.

Field, M.E., Gardner, J.V., and Prior, D.B., 1999, Geometry and significance of stacked gullies on the northern California slope. Marine Geology, v. 154, no. 1, p. 271-286.

Fildani, A., and Normark, W.R., 2004, Late Quaternary evolution of channel and lobe complexes of Monterey Fan. Marine Geology, v. 206, p. 199-223.

Fildani, A., Normark, W.R., Kostic, S., and Parker, G., 2006, Channel formation by flow stripping: large-scale scour features along the Monterey East Channel and their relation to sediment waves. Sedimentology, v. 53, no. 6, pp. 1265-1287.

Flood, R.D., Manley, P.L., Kowsmann, R.O., Appi, C.J., and Pirmez, C., 1991, Seismic facies and late Quaternary growth of Amazon submarine fan. in Weimer, P., and Link, M.H., eds., 1991, Seismic Facies and Sedimentary Processes of Submarine Fans and Turbidite Systems: New York (Springer), p. 415-433.

Frynas, J. G., 2004, The oil boom in Equatorial Guinea. African Affairs, v. 103, no. 413, p. 527-546.

Gay, A., Lopez, M., Cochonat, P., Sultan, N., Cauquil, E., Brigaud, F., 2003, Sinuous pockmark belt as indicator of a shallow buried turbiditic channel on the lower slope of the Congo Basin, West African Margin. in: Van Rensbergen P., Hillis R.R., Maltman A.J., Morley C.K., eds., 2003, Subsurface Sediment Mobilization. Geological Society of London, Special Publications, v. 216, p. 173-189. 
Gay, A., Lopez, M., Cochonat, P., Levaché, D., Sermondadaz, G., and Seranne, M., 2006a, Evidences of early to late fluid migration from an upper Miocene turbiditic channel revealed by 3D seismic coupled to geochemical sampling within seafloor pockmarks, Lower Congo Basin. Marine and Petroleum Geology, v. 23 , no. 3, p. 387-399.

Gay, A., Lopez, M., Cochonat, P., Séranne, M., Levaché, D., and Sermondadaz, G., 2006b, Isolated seafloor pockmarks linked to BSRs, fluid chimneys, polygonal faults and stacked Oligocene-Miocene turbiditic palaeochannels in the Lower Congo Basin. Marine Geology, v. 226, no. 1-2, p. 25-40.

Gervais, A., Savoye, B., Piper, D.J.W., Mulder, T., Cremer, M., and Pichevin, L., 2004, Present morphology and depositional architecture of a sandy confined submarine system: the Golo turbidite system (eastern margin of Corsica). in: Lomas, S.A., and Joseph, P., eds., 2004, Confined Turbidite systems. Geological Society of London Special Publications, v. 222, p. 59-89.

Gorsline, D.S., Kolpack, R.L., Karl, H.A., Drake, D.E., Fleischer, P., Thornton, S.E., Schwalbach, J.R., Savrda, C.E., 1984, Studies of fine-grained sediment transport processes and products in the California Continental Borderland. in: Stow, D.A.V., Piper, J.W., eds., 1984, Fine Grained Sediments: Deep Water Processes and Facies. Geological Society of London Special Publications, v. 15, p. 395-415.

Green, A., and Uken, R., 2008, Submarine landsliding and canyon evolution on the northern KwaZulu-Natal continental shelf, South Africa, SW Indian Ocean. Marine Geology, v. 254, no. 3-4, p. 152-170.

Harrington, P.K., 1985, Formation of pockmarks by pore-water escape, Geo-Marine Letters, v. 5, no. 3, p. 193-197.

Hedberg, H.D., 1926, The Effect of Gravitational Compaction on the Structure of Sedimentary Rocks. American Association of Petroleum Geologists Bulletin, v. 10, p. 1035-1072.

Heinio, P., and Davies, R.J., 2009, Trails of depressions and sediment waves along submarine channels on the continental margin of Espirito Santo Basin, Brazil. Bulletin of the Geological Society of America, v. 64, no. 11, p. 1295-1314. 
Hovland, M., and Sommerville, J.H., 1985, Characteristics of two natural gas seepages in the North Sea. Marine and Petroleum Geology, v. 2, no. 4, p. 319-326.

Hovland, M., and Judd, A.G., 1988, Seabed pockmarks and seepages: Impact on geology, biology, and the marine environment, Graham and Trotman, London, 293 p.

Hovland, M., Gardner, J.V. and Judd, A.G., 2002. The significance of pockmarks to understanding fluid flow processes and geohazards. Geofluids, v. 2, p. 127-136.

Howe, J.A., 1996, Turbidite and contourite sediment waves in the northern Rockall Trough, North Atlantic Ocean. Sedimentology, v. 43, no. 2, p. 219-234.

Huh, C. Liu, J.T., Lin, H., and Xu, J.P., 2009, Tidal and flood signatures of settling particles in the Gaoping submarine canyon (SW Taiwan) revealed from radionuclide and flow measurements. Marine Geology, v. 267, no. 1-2, p. 8-17.

Inman, D.L., Nordstrom, C.E., and Flick, R.E., 1976, Currents in Submarine canyons: An air-sea-land interaction. Annual Reivew of Fluid Mechanics, v. 8, p. 275-310.

Ivanov, M., Mazzini, A., Blinova, V., Kozlova, E., Laberg, J.-S., Matveeva, T., Taviani, M., Kaskov, N., 2010, Seep Mounds on the Southern Vøring Plateau (offshore Norway), Marine and Petroleum Geology, v. 27, no. 6, pp. 1235-1261.

Jobe, Z.R., and Hewlett, J., 2007, Neogene evolution of a confined upper slope canyon system with emphasis on canyon fill architecture, offshore Equatorial Guinea, American Association of Petroleum Geologists 2007 Annual Convention Abstracts with Program, Long Beach, CA.

Jourdin, F., Froidefond, J.M., Loyer, S., Lefèvre, C., Mayoyas, Y.K., Vrignaud, C., and Kolodziejczyk, N., 2006, Measuring upper ocean turbidity off Congo and Gabon coasts. CMM 2006 Caracterisation du Milieu Marin, 8 p.

Kassem, A., and Imran, J., 2001, Simulation of turbid underflows generated by the plunging of a river. Geology, v. 29, no. 7, p. 655-658.

Keller, G.H., and Shepherd, F.P., 1978, Currents and sedimentary processes in submarine canyons off the northeast United States. in: D.J. Stanley, D.J. and Kelling, G., eds., 1978, Sedimentation in Submarine Canyons, Fans and Trenches: Dowden, Hutchinson and Ross, Stroudsburg, Pennsylvania, p. 15-32. 
King, L.H., and MacLean, B., 1970, Pockmarks on the Scotian Shelf. American Association of Petroleum Geologists Bulletin, v. 81, no 10, p. 3141-3148.

Kolla, V., Bourges, P., Urruty, J.M., and Safa, P., 2001, Evolution of Deep-Water Tertiary Sinuous Channels Offshore Angola (West Africa) and Implications for Reservoir Architecture. American Association of Petroleum Geologists Bulletin, v. 85, no. 8, p. 1373-1405.

Kuenen, P.H., 1953, Origin and classification of submarine canyons. Bulletin of the Geological Society of America, v. 64, no. 11, p. 1295-1314.

Lawrence, S.R., Munday, S., and Bray, R., 2002, Regional geology and geophysics of the eastern Gulf of Guinea (Niger Delta to Rio Muni). The Leading Edge, v. 21, p. 1112.

Lehner, P., De Ruiter, P.A.C., 1977, Structural history of Atlantic margin of Africa. American Association of Petroleum Geologists Bulletin, v. 61, no. 7, p. 961-981.

Lowe, D.R., 1982, Sediment gravity flows: II. Depositional models with special reference to the deposits of high-density turbidity currents: Journal of Sedimentary Petrology, v. 52, no. 1, p. 279-297.

Magara, K., 1976, Water Expulsion from Clastic Sediments during Compaction: Directions and Volumes. American Association of Petroleum Geologists Bulletin, v. 60 , p. 543-553.

Marani, M., Argnani, A., Roveri, M., And Trincardi, F., 1993, Sediment drifts and erosional surfaces in the central Mediterranean: seismic evidence of bottomcurrent activity. Sedimentary Geology, v. 82, no. 1-4, p. 207-220.

Mariano, A.J., Ryan, E.H., Perkins, B.D., and Smithers, S., 1995, The Mariano global surface velocity analysis 1.0. United States Coast Guard Technical Report CG-D34-95, 55 p., National Technical Information Service, Springfield, VA.

Marzoli, A., Piccirillo, E.M., Renne, P.R., Bellieni, G., Iacumin, M., Nyobe, J.B. and Tongwa, A.T., 2000, The Cameroon Volcanic Line revisited: petrogenesis of continental basaltic magmas from lithospheric and astenospheric mantle sources. Journal of Petrology, v. 41, no. 1, p. 87-109. 
Mather, A.E., 2000, Impact of headwater river capture on alluvial system development; an example from the Plio-Pleistocene of the Sorbas Basin, SE Spain. Journal of the Geological Society of London, v. 157, no. 5, p. 957-966.

McGregor, B. Stubblefield, W.L., Ryan, W.B.F., Twichell, D.C., 1982, Wilmington submarine canyon: A marine fluvial-like system. Geology, v. 10, no. 1, p. 27-30.

McHargue, T.R., and Webb, J.E., 1986, Internal geometry, seismic facies, and petroleum potential of canyons and inner fan channels of the Indus submarine fan. American Association of Petroleum Geologists Bulletin, v. 70, no. 2, p. 161-180.

Meyers, J.B., Rosendahl, B.R., Groschel-Becker, H., Austin, J.A., and Rona, P.A., 1996, Deep penetrating MCS imaging of the rift-to-drift transition, offshore Douala and North Gabon basins, West Africa. Marine and Petroleum Geology, v. 13, no. 7, p. 791-835.

Meyers, J. B., Rosendahl, B. R., Harrison, C. G. A., and Ding, Z. D., 1998, Deep-imaging seismic and gravity results from the offshore Cameroon Volcanic Line, and speculation of African hotlines. Tectonophysics, v. 284, no. 1-2, p. 31-63.

Moore, D.G., 1969, Reflection profiling studies of the California Continental Borderland: structure, and Quaternary turbidite basins. Geological Society of America Special Paper no. 107, 142 p.

Mountjoy, J.J., Barner, P.M., Pettinga, J.R., 2009, Morphostructure and evolution of submarine canyons across an active margin: Cook Strait sector of the Hikurangi Margin, New Zealand. Marine Geology, v. 260, no 1-4, p. 45-68.

Nelson, C.H., 1990, Estimated post-Messinian sediment supply and sedimentation rates on the Ebro continental margin, Spain. Marine Geology, v. 95, no. 3-4, p. 395-418.

Noda, A., TuZino, T., Furukawa, R., Joshima, M., Uchida, J., 2008, Physiographical and sedimentological characteristics of submarine canyons developed upon an active forearc slope: The Kushiro Submarine Canyon, northern Japan. Bulletin of the Geological Society of America, v. 120, no. 5-6, p. 750-767.

Normark, W.R., 1970a, Growth patterns of Deep-Sea Fans. American Association of Petroleum Geologists Bulletin, v. 54, no. 11, p. 2170-2195. 
Normark, W.R., 1970b, Channel piracy on Monterey Deep-Sea Fan. Deep-Sea Research, v. 17, pp. 837-846.

Normark, W.R., and Carlson, P.R., 2003, Giant submarine canyons: Is size any clue to their importance in the rock record? in: Chan, M. A., and Archer, A. W., eds., 2003, Extreme Depositional Environments: Mega End Members in Geologic Time: Boulder, CO, Geological Society of America Special Paper 370, p. 175-190.

Normark, W.R., and Gutmacher, C.E., 1988, Sar submarine slide, Monterey fan, central California. Sedimentology, v. 35, no. 4, p. 629-647.

Normark, W.R. and Piper, D.J.W., 1991, Initiation processes and flow evolution of turbidity currents: implications for the depositional record. in: Osborne, R.H., ed., 1991, From Shoreline to Abyss: Contributions in Marine Geology in Honor of Francis Parker Shepard. SEPM Special Publications, v. 46, p. 207-230.

O'Connell, S., Ryan, W.B.F., and Normark, W.R., 1987, Modes of development of slope canyons and their relation to channel and levee features on the Ebro sediment apron, off-shore northeastern Spain. Marine and Petroleum Geology, v. 4, no. 4, p. 308-319.

Paull, C.K., Ussler, W. III, Greene, H.G., Mitts, P., Keaten, R., and Barry, J., 2003, Caught in the Act: 20 December 2001 Gravity Flow Event in Monterey Canyon. GeoMarine Letters, v. 22, p. 227-232.

Paull, C.K., Mitts, P., Ussler III, W., Keaten, R., Greene, H.G., 2005, Trail of sand in upper Monterey canyon: Offfshore California. Bulletin of the Geological Society of America, v. 117, no. 9-10, p. 1134-1145.

Peakall, J., McCaffrey, B., and Kneller, B., 2000, A process model for the evolution, morphology, and architecture of sinuous submarine channels: Journal of Sedimentary Research, v. 70, no. 3, p. 434-448.

Pilcher, R., and Argent, J., 2007, Mega-pockmarks and linear pockmark trains on the West African continental margin. Marine Geology, v. 244, no. 1-4, p. 15-32.

Piper, D.J.W., and Normark, W.R., 1983, Turbidite depositional patterns and flow characteristics, Navy submarine fan, California borderland: Sedimentology, v. 30, p. 681-694. 
Posamentier, H.W., 2003, Depositional elements associated with a basin floor channellevee system: case study from the Gulf of Mexico: Marine and Petroleum Geology, v. 20, no. 6-8, p. 677-690.

Posamentier, H., and V. Kolla, 2003, Seismic geomorphology and stratigraphy of depositional elements in deep-water settings. Journal of Sedimentary Research, v. 73, p. 367-388.

Pratson, L.F., Ryan, W.B.F., Mountain, G.S., and Twichell, D.C., 1994, Submarine canyon initiation by downslope-eroding sediment flows; evidence in late Cenozoic strata on the New Jersey continental slope. Bulletin of the Geological Society of America, v. 106, no. 3, p. 395-412.

Pratson, L.F., and Coakley, B.J., 1996, A model for the headward erosion of submarine canyons induced by downslope-eroding sediment flows. Bulletin of the Geological Society of America, v. 108, no. 2, p. 225-234.

Pratson, L.F., and Haxby, W.F., 1996, What is the slope of the U.S. continental slope? Geology, v. 24, no. 1, p. 3-6.

PYLES ET AL, 2010, TITLE, Marine and Petroleum Geology, v. XX, p. XX-XX.

Rebesco, M. Camerlenghi, A., Volpi, V., Neagu, C., Accettella, D., Lindberg, B., Cova1, A., Zgur1, F., and Magico Party, 2007, Interaction of processes and importance of contourites: insights from the detailed morphology of sediment Drift 7, Antarctica. in: Viana, A.R., and Rebesco, M., eds., 2007, Economic and palaeoceanographic significance of contourite deposits. Geological Society of London Special Publications, v. 276 p. 95-110.

Ross, D., and Hempstead, N., 1993, Geology, hydrocarbon potential of Rio Muni area, Equatorial Guinea. Oil \& Gas Journal, v. 91, p. 96-100.

Ross, W.C., Halliwell, B.A., May, J.A., Watts, D.E., and Syvitski, J.P.M., 1994, Slope readjustment; a new model for the development of submarine fans and aprons. Geology, v. 22, no. 6, p. 511-514.

Savini, A., Malinverno, E., Etiope, G., Tessarolo, C., and Corselli, C., 2009, Shallow seeprelated seafloor features along the Malta plateau (Sicily channel - Mediterranean Sea): Morphologies and geo-environmental control of their distribution. Marine and Petroleum Geology, v. 26, no. 9, p. 1831-1848. 
Sawyer, D.E., Flemings, P.B., Shipp, R.C., and Winker, C.D., 2007, Seismic geomorphology, lithology, and evolution of the late Pleistocene Mars-Ursa turbidite region, Mississippi Canyon area, northern Gulf of Mexico. American Association of Petroleum Geologists Bulletin, v. 91, no. 2, p. 215-234.

Seranne, M., Seguret, M., and Fauchier, M., 1992, Seismic super-units and post-rift evolution of the continental passive margin of southern Gabon. Bulletin de la Societe Geologique de France, v. 163, no. 2, p. 135-146.

Servain, J., Picaut, J., and Busalacchi, A., 1985, Interannual and seasonal variability of the tropical Atlantic ocean depicted by sixteen years of sea-surface temperature and wind stress. Elsevier Oceanography Series, v. 40, p. 211-237.

Shanmugam, G., Spalding, T.D., and Rofheart, D.H., 1993, Process sedimentology and reservoir quality of deep-marine bottom-current reworked sands (sandy contourites): an example from the Gulf of Mexico. American Association of Petroleum Geologists Bulletin, v. 77, no. 7, p. 1241-1259.

Shepard, F.P., 1936, The underlying causes of submarine canyons. Proceedings of the National Academy of Sciences, v. 22, no. 8, p. 496-502.

Shepard, F.P., 1981, Submarine canyons; multiple causes and long-time persistence. American Association of Petroleum Geologists Bulletin, v. 65, no. 6, p. 1062-1077.

Shepard, F.P., and Emery, K.O., 1973, Congo submarine canyon fan valley. American Association of Petroleum Geologists Bulletin, vol. 57, 1679-1691.

Shepard, F.P., McLoughlin, P.A., Marshall, N.F. and Sullivan, G.G., 1977, Current-meter recordings of low-speed turbidity currents. Geology, v. 5, p. 297-301.

Shipboard Scientific Party, 2002, Leg 194 summary. in: Isern A.R., Anselmetti, F.S., Blum, P., eds., 2002, ODP Proceedings, Initial Reports, v. 194, College Station, p. $1-88$.

Snedden, J.W., and Nummedal, D., 1988, Storm- and Fair-Weather Combined Flow on the Central Texas Continental Shelf. Journal of Sedimentary Research, v. 58, p. 580-595. 
Stow, D.A.V., and Bowen, A.J., 1980, A physical model for the transport and sorting of fine-grained sediment by turbidity currents. Sedimentology, v. 27, p. 31-46.

Stow, D.A.V., and Piper, D.J.W., 1984, Deep-water fine-grained sediments: Facies models. in: Stow, D.A.V., and Piper, D.J.W., eds., 1984, Fine-Grained Sediments: Deep-Water Processes and Facies, Geological Society of London Special Publication, v. 15, p. 611-645.

Stow, D.A.V., and Mayall, M., 2000, Deep-water sedimentary systems: new models for the 21st century. Marine and Petroleum Geology, v. 17, no. 2, p. 125-135.

Stow, D.A.V., Huc, A.Y., and Bertrand, P., 2001, Depositional processes of black shales in deep water. Marine and Petroleum Geology, v. 18, no. 4, p. 491-498.

Straub, K.M., and Mohrig, D., 2009, Constructional canyons built by sheet-like turbidity currents: Observations from offshore Brunei Darussalam. Journal of Sedimentary Research, v. 79, no. 1, p. 24-39.

Thornton, S.E., 1981, Suspended sediment transport in surface waters of the California Current off southern California: 1977-1978 floods. Geo-Marine Letters, v. 1, p. 2328.

Thornton, S.E., 1984, Hemipelagites and associated facies of slopes and slope basins. Geological Society of London, Special Publications, v. 15, p. 377-394.

Turner, J.P., 1995, Gravity-driven structures and rift basin evolution; Rio Muni Basin, offshore equatorial West Africa. American Association of Petroleum Geologists Bulletin, v. 79, no. 8, p. 1138-1158.

Turner, J.P., 1999. Detachment faulting and petroleum prospectivity in the Rio Muni Basin, Equatorial Guinea, West Africa. in: Cameron, N.R., Bate, R.H., Clure, V.S., eds., 1999, The Oil And Gas Habitats of the South Atlantic. Geological Society Special Publication, v. 153, p. 303-320.

Turner, J.P., Rosendahl, B.R., and Wilson, P.G., 2003, Structure and evolution of an obliquely sheared continental margin: Rio Muni, West Africa. Tectonophysics, v. 374, no. 1-2, p. 41-55. 
Twichell, D.C., and Roberts, D.G., 1982, Morphology, distribution, and development of submarine canyons on the United States Atlantic continental slope between Hudson and Baltimore canyons. Geology, v. 10, no. 8, p. 408-412.

Van Weering, T., Nielsen, T., Kenyon, N., Akentieva, K., and Kuijpers, A., 1998, Sediments and sedimentation at the NE Faeroe continental margin; contourites and large-scale sliding. Marine Geology, v. 152, no. 1-3, p. 159-176.

Viana, A.R., Hercos, C.M., De Almeida Jr, W., Magalhaes, J.L., and De Andrade, S.B., 2002, Evidence of bottom current influence on the Neogene to Quaternary sedimentation along the northern Campos Slope, SW Atlantic Margin. in: Stow, D.A.V., Pudsey, C.J., Howe, J.A., Faugeres, J-C., and Viana, A.R., eds., 2002, Deep-water contourite systems: modern drifts and ancient series, seismic and sedimentary characteristics. Memoirs of the Geological Society of London, v. 22 p. 249-259.

Whiticar, M.J., and Werener, F., 1981, Pockmarks: Submarine vents of natural gas or freshwater seeps? Geo-Marine Letters, v. 1, no. 3-4, p. 193-199.

Williams, E.G., Guber, A.L., and Johnson, A.M., 1965, Rotational slumping and the recognition of disconformities. Journal of Geology, v. 73, p. 534-547.

Wilson, P.G., Turner, J.P., and Westbrook, G.K., 2003, Structural architecture of the ocean-continent boundary at an oblique transform margin through deep-imaging seismic interpretation and gravity modelling: Equatorial Guinea, West Africa. Tectonophysics, v. 374, no. 1-2, p. 19-40.

Wright, L.D., Wiseman, W.J. Bornhold, B.D., Prior, D.B., Suhayda, J.N., Keller, G.H., Yang, L.S., and Fan, Y.B., 1988, marine dispersal and deposition of Yellow river silts by gravity-driven underflows. Nature, v. 332, p. 629-632.

Wynn, R.B., Weaver, P.P.E., Ercilla, G., Stow, D.A.V., and Masson, D.G., 2000, Sedimentary processes in the Selvage sediment-wave field, NE Atlantic: new insights into the formation of sediment waves by turbidity currents. Sedimentology, v. 47., no. 6, p. 1181-1197.

Yu, H., Chiang, C., and Shen, S., 2009, Tectonically active sediment dispersal system in SW Taiwan margin with emphasis on the Gaoping (Kaoping) Submarine Canyon: Journal of Marine Systems, v. 76, no. 4, p. 369-382. 
Zhu, M., 2007, Offshore Red River Fault and slope sediments in northern South China Sea: Implications for Paleoceanography and uplift of the Tibet Plateau: Ph.D. thesis, Stanford University, 202 p.

Zhu, M. Graham, S.A., Pang, X., and McHargue, T., 2009, Characteristics of migrating submarine canyons from the middle Miocene to present: Implications for paleoceanographic circulation, northern South China Sea. Marine and Petroleum Geology, v. 27, no. 1, p. 307-319. 